Universidade de Brasília

Faculdade de Direito

\title{
O CONSEQUENCIALISMO E O ESTADO DE DIREITO NA MODULAÇÃO DE EFEITOS EM MATÉRIA TRIBUTÁRIA
}

ALAN MARQUES COSMO

Brasília, Novembro de 2011 
Universidade de Brasília - UnB

Faculdade de Direito

ALAN MARQUES COSMO

\section{O CONSEQUENCIALISMO E O ESTADO DE DIREITO NA MODULAÇÃO DE EFEITOS EM MATÉRIA TRIBUTÁRIA}

Monografia apresentada como requisito parcial à obtenção do título em bacharel em Direito pela Faculdade de Direito da Universidade de Brasília UnB.

Orientador: Othon de Azevedo Lopes

\section{BRASÍLIA}




\section{Agradecimentos}

Em primeiro lugar, aos meus pais, Gilvam e Suzi, e aos meus irmãos, Elizabeth e Gabriel, pelo amor, carinho, paciência, incentivo e apoio durante toda a minha vida. Com palavras ou atitudes, sempre ofereceram o suporte necessário para que eu pudesse seguir em frente.

Ao meu orientador, Othon de Azevedo Lopes, pelos ensinamentos dentro de sala de aula e por toda a sua atenção durante a realização deste trabalho.

Aos membros da banca, Ricardo Barretto e Tiago Conde, pelas lições transmitidas e pelas contribuições para o aprimoramento deste estudo.

Aos meus amigos, que sempre torceram pelo meu sucesso e que sempre me deram força e alegria para superar os desafios: Yumi, Rafael, Pedro, Mara, Maria, Pedro Neiva, Marcela, Beatriz, João, Juliana, André, Beatriz Leal, Adriana, Thaís, Saulo, Stefano, Vitor, Marcus, Mateus e Angelo.

Aos meus colegas da Universidade de Brasília verdadeiros amigos que ganham parágrafo em separado apenas por terem participado mais de perto da graduação , em especial: Fernanda, Priscila, Paula, Uiára, Lucas e Fernanda Kawano.

À Camila, por ter compartilhado esses últimos cinco anos de graduação, pela ajuda na elaboração deste trabalho e, principalmente, pela amizade, que trouxe muita felicidade e crescimento para a minha vida.

A todos vocês, que, de alguma forma, são marcantes na minha vida.

Muito obrigado! 


\section{RESUMO}

Esta monografia envolve a pesquisa do fenômeno do consequencialismo aqui entendido como qualquer programa teórico-argumentativo que tenha objetivo ou que condicione, de forma explícita ou velada, a adequação jurídica de uma decisão às suas conseqüências influenciou na mitigação dos efeitos das decisões ex tunc, bem como nos efeitos da alteração de jurisprudência consolidada. Para tanto, faz-se um breve esboço do tema no entendimento estrangeira (especificamente austríaco e norte-americano) e brasileira. Em seguida, estuda-se o fenômeno do Estado de Direito, mostrando como os pilares dessa construção teórica foram delineados tão-somente para a proteção dos interesses individuais, sujeitando o Estado à observância do quanto previsto no ordenamento jurídico, refreando eventual tendência do poder político a se expandir de maneira arbitrária, e a tutela dos direitos individuais. Por fim, escolhem-se quatro casos, que envolvem questões de Direito Tributário, recentemente julgados no STF, para examinar se os fundamentos jurídicos encampados na nossa Constituição permitem a inclusão das consequências das decisões na sua razão de decidir.

PALAVRAS-CHAVE: Direito Tributário; Consequencialismo; Declaração de inconstitucionalidade; Modificação de jurisprudência; Estado de Direito; Limitação do poder de tributar; Direitos do cidadão; Segurança jurídica; 


\section{Índice de Siglas}

ADI Ação Direta de Inconstitucionalidade

ADC Ação Declaratória de Constitucionalidade

ADPF Ação de Descumprimento de Preceito Fundamental

AI Agravo de Instrumento

COFINS Contribuição para o Financiamento da Seguridade Social

CPC Código de Processo Civil

CTN Código Tributário Nacional

CF Constituição Federal

FUNRURAL Contribuição do Empregado Rural para a Seguridade Social

LC Lei Complementar

IPI Imposto sobre Produtos Industrializados

RE Recurso Extraordinário

STF Supremo Tribunal Federal

STJ Superior Tribunal de Justiça 


\section{Sumário}

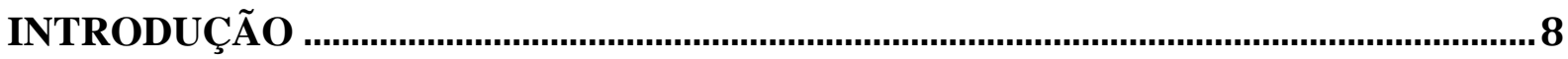

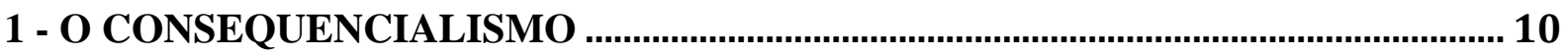

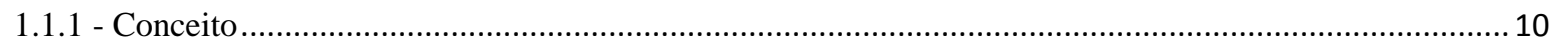

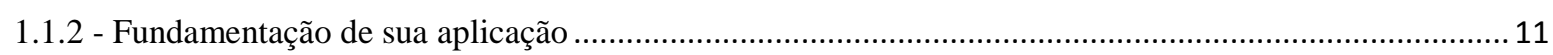

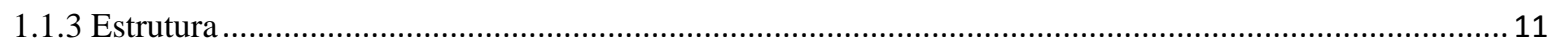

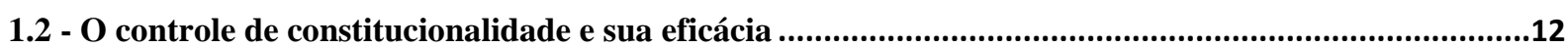

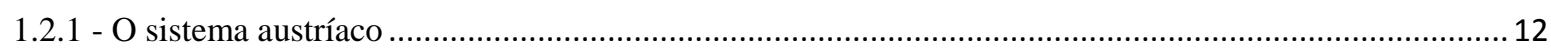

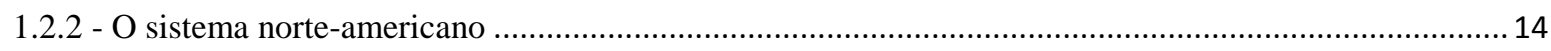

1.3 - As decisões de inconstitucionalidade e a influência do consequencialismo no Brasil ...........................18

1.3.1 - As primeiras resistências na tese da eficácia ex tunc .................................................................. 18

1.3.2 Oposição do Supremo Tribunal Federal ao argumento da consequência ...............................................21

1.3.3 - O argumento da consequência em questões não-tributárias..........................................................24

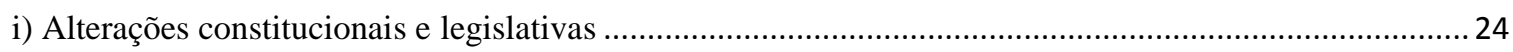

ii) a aplicação do artigo 27 da Lei 9.868/99 em matérias não-tributárias ....................................................26

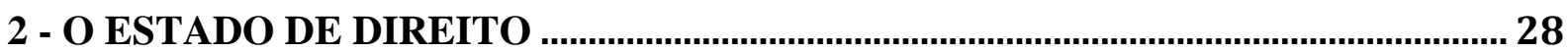

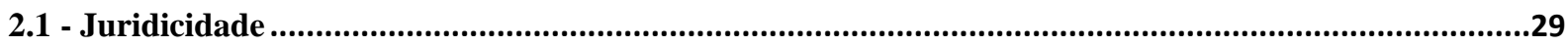

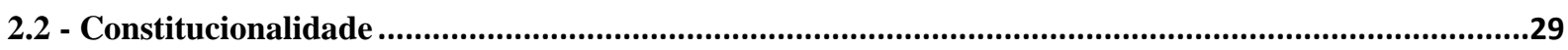

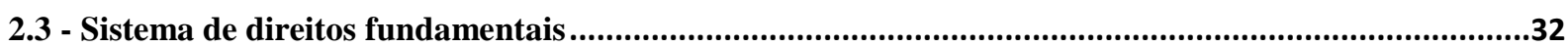

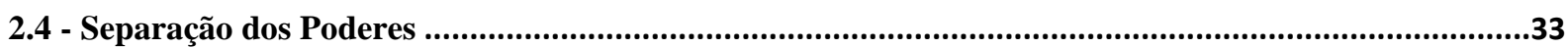

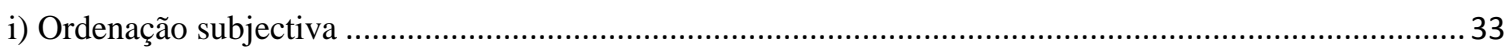

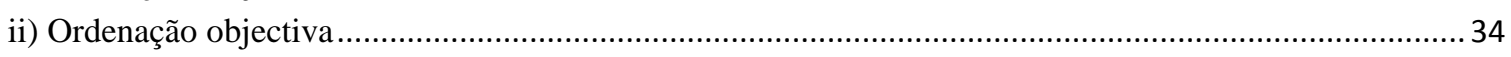

2.5 - Os subprincípios concretizadores do Estado de Direito ............................................................36

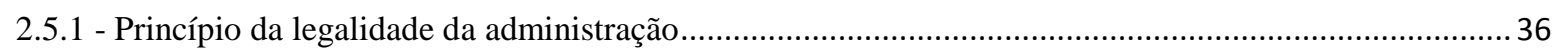

2.5.2 - Os princípios da segurança jurídica e da proteção da confiança dos cidadãos ..................................38

\section{3 - A MODULAÇÃO DE EFEITOS EM MATÉRIA TRIBUTÁRIA: REQUISITOS E} ANÁLISE CRÍTICA DA JURISPRUDÊNCIA DO STF.................................................... 41

3.1 - O imperativo da aplicação do instituto da modulação de efeitos quando a decisão vai de encontro aos interesses do contribuinte e a sua impossibilidade quando a decisão é a favor do Fisco.............................41

3.2 - Modulação de efeitos em matéria tributária: casos da jurisprudência do STF ..................................44

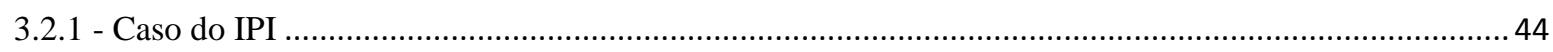

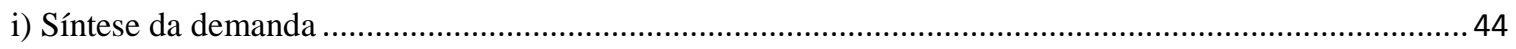

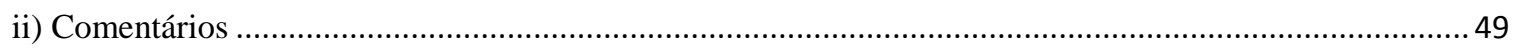

3.2.2 Caso da decadência e prescrição das contribuições sociais ...............................................................52

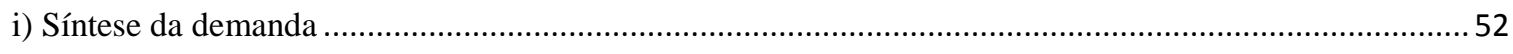

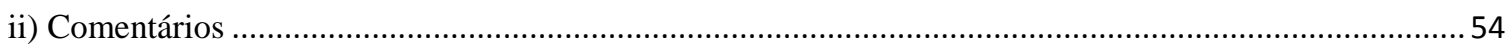


3.2.3 - O caso da isenção da COFINS às sociedades civis de prestação de serviços com profissão regulamentada

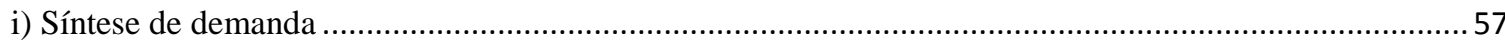

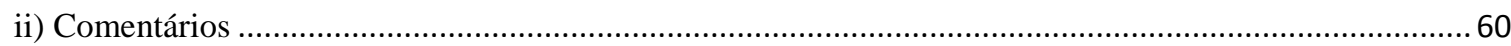

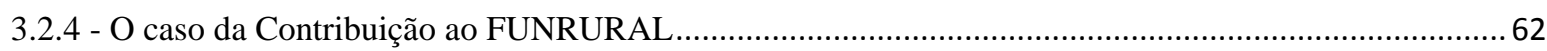

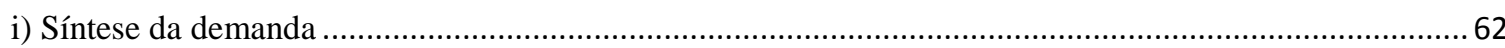

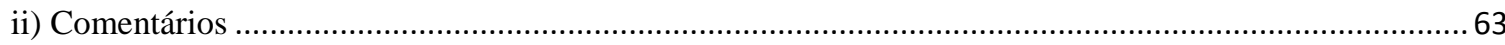

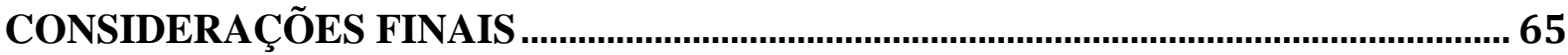

REFERÊNCIAS BIBLIOGRÁFICAS .......................................................................... 67 


\section{Introdução}

A possibilidade dada ao Supremo Tribunal Federal de modular os efeitos de suas decisões com a consequente influência nas relações sociais é um tema da maior importância para o ordenamento jurídico, uma vez que acaba por dispor acerca da possibilidade da aplicabilidade de uma norma (seja por lhe restringir os efeitos, seja por determinar a sua permanência mesmo quando tida por inconstitucional) e para a confiança no judiciário pátrio.

Além disso, alterações jurisprudenciais inesperadas acabam por representar uma ameaça à confiabilidade dos órgãos jurisdicionais (circunstância que ensejaria o emprego dos efeitos prospectivos) e à própria sociedade, por ser impossível ignorar a influência que tais decisões causam na vida das pessoas e no funcionamento do Estado.

Nesse contexto, apresenta-se como de fundamental importância a análise da forma em que tal questão aparece no Pretório Excelso, limitando-se o estudo às questões de Direito Tributário. Isto é, convém perquirir de que maneira o Supremo Tribunal Federal (STF) vem dirimindo tais casos que lhe são apresentados, colocando-os sob o crivo doutrinário e jurisprudencial da Corte.

Tendo isso em mente, inicia-se o trabalho apontando como o consequencialismo é capaz de influenciar no processo de tomada de uma decisão por um Tribunal. Quer dizer, quando os julgadores, além de discutir a questão de direito que lhes é posta, passam também a vislumbrar quais serão (ou seriam) os seus efeitos.

Logo após tal exposição, apresentam-se brevemente os dois principais sistemas de declaração de inconstitucionalidade de normas o austríaco e o norte-americano , uma vez que é impossível ignorar a influência que esses métodos exerceram, e ainda exercem, na jurisprudência e na doutrina pátria. Concomitantemente, aduzem-se as críticas que são feitas a ambos, além de se mostrar como o argumento da consequência influenciou também a mitigação dos dois sistemas, especialmente o estadunidense.

Em seguida, é feita uma síntese histórica de como o STF encara a modulação de efeitos. Para tanto, é traçada uma divisão da atuação do Tribunal em quarto períodos: (i) o da introdução de temperamentos na tese da eficácia ex tunc; (ii) o da resistência ao consequencialismo no período que se inicia com o agravamento do positivismo; (iii) o da adesão ao argumento da consequência em questões não tributárias; (iv) o da extensão do consequencialismo em matéria tributária.

Antes de pôr à vista esse último ponto, faz-se uma pausa para se analisar quais seriam os elementos essenciais de um Estado de Direito, na visão do constitucionalista português 
José Joaquim Gomes Canotilho. Tal concepção, alinhada com outros ensinamentos doutrinários, trará os subsídios necessários para o exame crítico da jurisprudência do STF com relação à aplicação dos efeitos prospectivos em temas tributários.

Por fim, analisam-se julgados envolvendo o tema deste estudo. Para tanto, quatro julgados foram selecionados: a questão da prescrição e decadência das contribuições previdenciárias; o direito ao crédito presumido do IPI na aquisição de produtos não-tributados ou sujeitos à alíquota zero; a isenção da COFINS às sociedades civis de prestação de serviços com profissão regulamentada; e o caso em que se discutiu a contribuição ao FUNRURAL.

Após tal tarefa, espera-se chegar a uma conclusão sobre qual tem sido a tendência da jurisprudência do Supremo Tribunal Federal ao examinar os pedidos de efeitos prospectivos às suas decisões. Ademais, deseja-se conhecer se tal inclinação vai ao encontro da jurisprudência da Corte, bem como saber se realiza o seu mister constitucional, ou se as suas decisões estão muito mais carregadas com a preocupação de suas consequências. 


\title{
1 - O consequencialismo
}

\subsection{1 - Conceito}

Ainda que não se desconheça as várias teorias que buscam trazer argumentos exógenos ao Direito para fundamentar as decisões, neste trabalho tratar-se-á a expressão lato, isto é, referindo-se a qualquer programa teóricoargumentativo que tenha objetivo ou que condicione, de forma explícita ou velada, a adequação jurídica de uma decisão às suas consequências. ${ }^{1}$

Para maior delimitação, utiliza-se aqui a definição proposta por Ricardo Lobo Torres:

\begin{abstract}
O argumento consequencialista é utilizado no discurso de aplicação do direito e consiste na consideração das influências e das projeções da decisão judicial boas ou más no mundo fático. Efeitos econômicos, sociais e culturais prejudiciais ou favoráveis à sociedade devem ser evitados ou potencializados pelo aplicador da norma, em certas circunstâncias.

Depende, portanto, da permanente tensão entre valores e princípios, de um lado, e faticidade, do outro. É fruto da jurisprudência dos princípios. (TORRES, 2010, p. 20)
\end{abstract}

Posta essa questão, o juiz vai analisar o caso concreto e decidirá ponderando tais polos com a questão jurídica. Trata-se, nesse caso, de um papel político exercido pelo Poder Judiciário. Por papel político entendemos o mesmo que foi dito por Manoel Gonçalves Ferreira Filho:

Por papel político, aqui se entende não uma atuação em prol de interesses partidários, mas uma participação ativa na conformação da ordem constitucional, da ordem jurídica infraconstitucional e também na definição de rumos administrativos, nisto incluídas as políticas públicas. FERREIRA FILHO (2008, p. 86)

O juiz, por não ser um homem isolado do mundo, acaba levando em consideração circunstâncias que são alheias ao limitado universo dos autos, deixando de prática subsunção mecânica de fato à norma, como viva vox legis trazendo em sua decisão elementos fáticos, dando forma aos princípios encampados na Constituição e demais diplomas legais.

Nesses casos, ele acaba por fazer as vezes de um árbitro de interesses que, não raro, acabam por transcender os limites dos interesses individuais defendidos pelas partes nos ,decidindo qual a solução que melhor se adéqua à situação concreta. Ele não é apenas um mero aplicador do Direito.

${ }^{1}$ Convém aduzir que tal medida não chega a ser inovadora. Com proposta semelhante encontramos ANDRADE, 2011, p.73; e LEAL, 2010, p.17. 


\subsection{2 - Fundamentação de sua aplicação}

Ricardo Lobo Torres (2010) aponta que o consequencialismo apresenta seus alicerces no próprio sistema jurídico, estando ligado ao Estado Ponderador e se fundamentando em seus valores e princípios.

O modelo atual de Estado de Direito traz em seu bojo uma série de características que o faz ser essencialmente um Estado Ponderador. Dessa forma, o legislador, ou mesmo o aplicador do Direito, tem de frequentemente ponderar quais valores e princípios jurídicos devem prevalecer em cada situação.

Nesse contexto, deve-se ter em mente que as normas jurídicas nem sempre alcançam o resultado desejado que motivou a sua criação. Ao se editar uma norma, o legislador, imerso nesse contexto de sopesamento de situações e de medidas, pode vir a cometer equívocos resultados que não correspondiam a sua ideia inicial ou que acabam prejudicando demasiadamente um grupo em detrimento de um benefício para outro, que podem ser jurídicos ou mesmo políticos, os quais serão integrados pelo Judiciário. Para melhor elucidação do tema, buscamos auxílio nas palavras de Ricardo Lobo Torres:

\footnotetext{
A lei nem sempre produz o resultado almejado pelo legislador democrático: em razão da ambivalência e da insegurança típicas da sociedade de risco, há uma distribuição não só de benefícios, como se pretendia ao tempo do Estado de Bemestar-Social, mas também de malefícios. O trabalho do juiz será, então, o de complementar e integrar o ordenamento, recorrendo ao raciocínio de custo/benefício ou de ponderação de políticas. (TORRES, 2010, p .22.)
}

Diante do exposto, deve-se destacar a ligação do consequencialismo ao Estado Ponderador, uma vez que a sua existência está relacionada à ponderação de princípios.

\subsubsection{Estrutura}

Além disso, é preciso destacar que o consequencialismo não aparece em qualquer momento. Ele depende que a estrutura normativa que fundamenta a decisão judicial lhe seja favorável. Assim, por um lado, normas que prescrevem apenas uma confirmação de uma condição, aquelas que são eminentemente causais se algo acontece, então temos o seguinte resultado , não são passíveis de sua aplicação.

Por outro lado, aquelas normas que trazem em seu conteúdo alguma finalidade que estão abertas para a prognose ou para a determinação de finalidades são suscetíveis ao emprego do instituto.

Esse tema fica bem esclarecido ao analisarmos a entrevista que Nelson Jobim concedeu ao jornal Valor Econômico, quando era ministro do Supremo Tribunal Federal. Ao 
assim respondeu:

\begin{abstract}
Quando só há uma interpretação possível, acabou a história. Mas quando há um leque de interpretações, por exemplo cinco, todas elas são justificáveis e são logicamente possíveis. Aí, deve haver outro critério para decidir. E esse outro critério é exatamente a conseqüência, no meio social, da decisão A, B ou C? Você tem de avaliar, nesses casos muito pulverizados, as consequiências. Você pode ter uma conseqüência no caso concreto eventualmente injusta, mas que no geral seja positiva. E é isso que eu chamo da responsabilidade do Judiciário das conseqüências de suas decisões. ${ }^{2}$
\end{abstract}

Com tais palavras, o então Ministro do STF esclareceu, na sua visão, quais são as condições para a aplicação do consequencialismo nas decisões da Corte.

\title{
1.2 - O controle de constitucionalidade e sua eficácia
}

Essa exposição anterior acerca do consequencialismo vai ser importante para uma melhor compreensão dos dois principais sistemas de controle de constitucionalidade: o americano, que não admite, em regra, o consequencialismo; e o austríaco, que traz o seu argumento como padrão.

\subsection{1 - O sistema austríaco}

Nesse modelo, bastante influenciado pelas ideias de Hans Kelsen, temos que a declaração de inconstitucionalidade de uma norma jurídica fará com que os efeitos de tal estabelecimento só influenciem o Direito a partir da publicação da decisão. As razões para a adoção de tal sistema ficam mais bem entendidas nas palavras do aludido jurista:

Não é, portanto, correto o que se afirma quando a decisão anulatória da lei é sua decis ex tunc). A sua decisão não tem caráter simplesmente declarativo, mas constitutivo. O sentido do ato pelo qual uma norma é destruída, quer dizer, pelo qual a sua validade é anulada, é, tal como o sentido de um ato pelo qual uma norma é criada, uma norma. A ordem jurídica somente pode conferir a um determinado órgão poder para anular uma norma criada por outro órgão, mas pode atribuir poder a quem quer que seja para decidir se algo que surge com a pretensão de ser uma norma jurídica tem objetivamente esta significação, quer dizer: se a norma foi produzida pela forma determinada pela ordem jurídica e com o conteúdo por esta mesma ordem jurídica fixado, e, portanto, se é vinculante para ele. (KELSEN, 2006, p. 307)

De acordo com tal doutrina, portanto, a lei deveria ser tida como válida até que o órgão competente para retirá-la do ordenamento assim se pronunciasse. Evidentemente, tal

\footnotetext{
${ }^{2}$ A íntegra da entrevista pode ser obtida em:

http://www.stf.jus.br/arquivo/biblioteca/PastasMinistros/NelsonJobim/Entrevistas/2004_dez_13.pdf (Acesso em 30.09.2011)
} 
teoria traz, de um lado, em si a vantagem de evitar aplicações divergentes da norma, isto é, faz com que ninguém se recuse a aplicar determinado diploma sob o fundamento de sua inconstitucionalidade (GARCIA, 2010).

Além disso, encontramos aqui o argumento da necessidade de resguardar o Direito contra a descontinuidade, aproximando-se de um equilíbrio entre segurança jurídica e o princípio da constitucionalidade. ${ }^{3}$

Por outro lado, a crítica mais severa que se pode fazer a tal sistema é a de que ele permite a sobrevivência, por um período determinado, de lei flagrantemente inconstitucional, com todos os seus efeitos. O perigo de tal prática é notável: compromete a supremacia constitucional, uma vez que mitiga a sua rigidez.

Por fim, convém registrar que tal sistema não ficou infenso à aplicação dos efeitos $e x$ tunc da declaração de inconstitucionalidade. Isso pode ser observado na lição de Ricardo Lobo Torres:

O sistema austríaco, reformado em 1929, mitigou a regulamentação de 1920 , com reconhecer a possibilidade de aplicar retroativamente a decisão que declara a inconstitucionalidade ao caso concreto que a motivou em via de exceção. E o próprio Kelsen introduziu algumas modificações em sua doutrina, para admitir a invalidade da lei $a b$ initio, por defeitos relacionados com a sua formação, que não seria uma declaração de nulidade (Nichtigkeiterklärung), mas uma anulação com eficácia retroativa (rückwirkende Vernichtung). (TORRES, 2010, p. 28.)

Reforçando a afirmação, é de se conferir o seguinte trecho da obra de Kelsen:

Uma norma jurídica em regra somente é anulada com efeitos para futuro, por forma
que os efeitos já produzidos que deixa para trás permanecem intocados. Mas
também pode ser anulada com efeito retroativo, por forma que os efeitos que deixa
para trás permanecem intocados. Mas também pode ser anulada com efeito
retroativo, por forma tal que os efeitos jurídicos que ela deixou atrás de sei sejam
destruídos: tal, por exemplo, a anulação de uma lei penal, acompanhada da anulação
de todas as decisões judiciais proferidas com base nela; ou de uma lei civil,
acompanhada da anulação de todos os negócios celebrados e decisões jurisdicionais
proferidas com fundamento nessa lei. Porém, a lei foi válida até a sua anulação. Ela
não era nula desde o início. (KELSEN, 2006, p. 306)

Diante do exposto, fica claro que o sistema percebeu que a permanência de alguns efeitos de uma lei inconstitucional não seriam desejáveis, devendo-se, assim, mitigar a regra da eficácia prospectiva em determinadas situações. Ou seja, a manutenção da lei não seria interessante em alguns casos. Tal como exemplificado por Kelsen (2006), os efeitos da

\footnotetext{
${ }^{3}$ Ainda com relação ao tema, TORRES (2010, p. 28) aduz que Kelsen apresentava que o sistema tinha a vantagem de evitar o vácuo (Valkuum) normativo, uma vez que tal modulação de efeitos permitiria que o Legislativo substituísse a lei inconstitucional.
} 
manutenção de uma lei inconstitucional incriminadora, por exemplo, poderiam não ser desejados.

\subsection{2 - O sistema norte-americano}

A Constituição norte-americana não contém em seu texto nenhuma norma que regulamente o controle de constitucionalidade. Com isso, coube à jurisprudência estabelecer tal possibilidade. O primeiro caso em que se tem notícia de que esse judicial review foi aplicado é o do requerimento de Marbury, resultando no Marbury v. Madison (MENDES, 2009; GARCIA, 2010), no qual se solicitava à Suprema Corte Americana um mandamus que obrigasse o secretário de Estado, Madison, a lhe dar posse no cargo em que fora indicado.

Ainda que o caso seja bastante interessante, convém restringi-lo ao ponto deste estudo: que os atos legislativos estão sujeitos ao controle do Judiciário. A respeito convém destacar trecho do que foi consignado pelo justice Marshall, presidente da Corte:

Thus, the particular phraseology of the Constitution of the United States confirms and strengthens the principle, supposed to be essential to all written Constitutions, that a law repugnant to the Constitution is void, and that courts, as well as other departments, are bound by that instrument. ${ }^{4}$

Tal decisão, juntamente com o princípio do stare decisis, o qual faz com que haja uma generalização do precedente judicial, valendo erga omnes, levou a Suprema Corte estadunidense, a partir de então, a admitir a possibilidade de os tribunais a ela submetidos analisarem a constitucionalidade de uma lei. Além disso, retira-se de tal julgado que a lei declarada inconstitucional deve ser tida como nula. Tal teoria encontrou o respaldo jurisprudencial nos anos subsequentes, tal como podemos observar nas palavras de Thomas Cooley:

Indeed, the term unconstitucional law, in American jurisprudence, is a misnomer and implies a contradiction; that enactment which is opposed to the Constitution being in fact no law at all. ${ }^{5}$ (COOLEY, 1868, p. 3)

Fundada nessa doutrina que recusava oferecer algum valor a uma lei inconstitucional, os constitucionalistas americanos passaram a entender que tal diploma seria inválido ab initio: isto é, jamais produziu efeitos, vez que eles seriam contrários a uma norma superior

\footnotetext{
$4 \quad$ eforça o

princípio, supostamente tido como essencial em todas as Constituições escritas, de que uma lei contrária à Constituição é nula, e que os 
(TORRES, 2010). Segundo tal entendimento, conferir eficácia a tais atos importaria na suspensão provisória ou parcial da Constituição (MENDES, 2009).

A adoção da eficácia ex tunc na declaração de inconstitucionalidade, adotada por esse sistema, sofreu, no decorrer do tempo, alguns ajustes, passando a admitir o rompimento do dogma de que a nulidade de uma lei conduziria à retroatividade dos efeitos de sua declaração. Com relação ao tema, André Ramos Tavares (2010) aponta o caso Linkletter versus Walker como paradigma da questão, do qual extraímos o seguinte excerto:

\footnotetext{
Once the premise is accepted that we are neither required to apply, nor prohibited from applying, a decision retrospectively, we must then weigh the merits and demerits in each case by looking to the prior history of the rule in question, its purpose and effect, and whether retrospective operation will further or retard its operation. ${ }^{6}$
}

Como se vê, a adesão ao consequencialismo é notável em tal trecho. Ao determinar que há necessidade de o julgador sopesar os méritos e os deméritos em cada decisão, para estabelecer se deve aplicar efeitos retroativos ou prospectivos à decisão, não resta dúvida de que a consequência no mundo fático é fundamental para se saber qual o efeito será dado ao ato decisório.

Ainda com relação ao tema da mitigação dos efeitos ex tunc na doutrina americana, convém agora trazer à baila um interessante caso daquele país, no qual se debate uma questão de Direito Tributário.

A Suprema Corte americana no caso Davis v. Michigan Department of the Treasury ${ }^{7}$ declarou a inconstitucionalidade da tributação estadual em benefícios previdenciários efetuados pelo governo federal, uma vez que haveria, com isso, ofensa à imunidade tributária entre membros do governo, pois benefícios idênticos pagos pelos Estados e suas divisões políticas eram isentos.

Diante de tal caso, pretenderam os contribuintes sujeitos a tal tributação inválida a restituição dos valores indevidamente pagos, sob o argumento da retroatividade de tal julgado. Em um primeiro momento, a Suprema Corte Estadual de Virgínia negou-lhes tal pretensão (TORRES, 2010), com fulcro em um precedente da Suprema Corte dos Estados Unidos

\footnotetext{
6 decisão retroativa, nós devemos então pesar os méritos e deméritos de cada caso olhando a história da regra em questão, o seu propósito e 
(Chevron Oil Co. v. Huson ${ }^{8}$ ), o qual estabelecera a possibilidade de se rejeitar a retroatividade do julgado quando se fixasse um novo princípio de direito. ${ }^{9}$

Tal questão a de restituição dos valores indevidamente pagos aos estados de impostos incidentes em benefícios previdenciários acabou sendo levada à Suprema Corte no caso Harper ET AL. v. Virginia Department of the Treasury ${ }^{10}$, que acabou reformando a decisão anteriormente proferida. Com isso, não foi aplicado o que fora estabelecido no caso Chevron Oil Co. v. Huson. Dessa decisão, convém destacar alguns pontos. O primeiro deles diz respeito de que o efeito retroativo é a regra, devendo ser estabelecido em todos os casos sujeitos à revisão e a todos os eventos, ainda que anteriores ou posteriores à divulgação da norma. Isso ficou assim consignado:

When this Court applies a rule of federal law to the parties before it, that rule is the
controlling interpretation of federal law and must be given full retroactive effect in
all cases still open on direct review and as to all events, regardless of whether such
events predate or postdate the announcement of the rule.
(...)
When the Court does not reserve the question whether its holding should be applied
to the parties before it, the opinion is properly understood to have followed the
normal rule of retroactive application, and the legal imperative to apply such a rule
11

Além disso, a decisão enfatiza que o caso Chevron Oil não poderia servir como paradigma para a irretroatividade invocada nesse caso porque, além de contrariar outros casos precedentes, em virtude das peculiaridades do caso que estabeleceram o precedente, seria resultante do ativismo judicial. ${ }^{12}$

Ainda argumentando contrariamente à aplicação dos efeitos prospectivos, encontramos o trecho no voto do justice The true traditional view is that prospective decisionmaking is quite incompatible with the judicial power, and that courts have no authority to engage in the practice. ${ }^{13}$

\footnotetext{
8404 U.S. 97 (1971)

${ }^{9} 404$ U.S 97 (1971). Do julgado, ex considered(...) [that]

casos lidando com a questão não-retroativa, nós geralmente consideramos (...) [que] a decisão a ser aplicada não-retroativamente deve

10 509 U.S. $86(1993)$

11509 U.S. 86 (1993).

a uma norma de lei federal às partes, tal norma é a interpretação controladora do direito federal e deve ter pleno efeito retroativo em todos os casos ainda sujeitos à revisão e a todos os eventos, independentemente da circunstância de que tais eventos sej

Corte não reserva a questão de se saber se a sua influência deve ser aplicada às partes antes disso, a opinião dominante é de que se deve seguir a regra normal do efeito retroat 
A partir de tal excerto, fica bem claro que a Corte americana rechaça, em regra, a aplicação de efeitos prospectivos por considerá-los uma forma de atuação em um terreno que não lhes pertence: o Legislativo.

De acordo com Ricardo Lobo Torres, tal decisão foi alvo de severas críticas pela doutrina norte-americana. $\mathrm{O}$ autor traz os argumentos que embasavam tal censura:

Em primeiro lugar, porque não seria eqüitativo que a decisão inesperada, que introduziu direito novo, anulasse relações pretéritas livremente estabelecidas sob a égide da legislação que não se encontrava sob a suspeita de ilegitimidade constitucional. Depois, porque o objetivo da eficácia retroativa é proteger o cidadão law

new

Tesouro Público, inclusive por falta de previsão orçamentária, problema que se tornou particularmente grave com a extensão da decisão proferida em Davis a outros 23 estados que adotaram legislação semelhante. (TORRES, 2010, p. 27)

Como se nota, a doutrina não acolheu os argumentos de que a modulação dos efeitos na decisão em comento seria uma forma de se evitar com que o julgador fizesse as vezes de legislador, sob o argumento de que tal inércia acabara, na verdade, fazendo com que uma regra inesperada surtisse efeitos indesejáveis.

Apenas para encerrar a discussão desse caso e da mitigação na doutrina clássica dos efeitos ex tunc da decisão que declara a inconstitucionalidade de uma lei, convém apenas destacar que tal caso Harper ET AL v. Virginia Department of Treasury apresenta ainda outra consequência importante. Após tal julgamento, que acabaria por prejudicar vários Estados que adotaram regulamentação semelhante, diversos entes federativos, vislumbrando desfalque no caixa, valeram-se de brechas no julgado para adotar as seguintes medidas:

a) diminuição do prazo de prescrição para repetir o indébito; b) novos critérios para determinar o dano ao tesouro que possa inviabilizar o remédio; c) exigência de que o contribuinte haja, antes da decisão declaratória da inconstitucionalidade, ajuizado ação contra a

decision invalidating the tax ${ }^{14}$ (TORRES, 2010, p. 28)

Tais providências acabaram por fazer com que a decisão proferida pela Suprema Corte não abrangesse todos os casos, pela inconstitucionalidade da norma.

Tal exposição acabou por demonstrar como se deu a evolução dos principais modelos de eficácia das decisões que declaram a inconstitucionalidade de uma lei. Agora, vamos ver qual modelo o Brasil adotou, bem como aconteceu a sua evolução. 


\section{3 - As decisões de inconstitucionalidade e a influência do consequencialismo no Brasil}

Na lição trazida por Ricardo Lobo Torres, o consequencialismo, nas últimas décadas, apresentou quatro fases: introdução de temperamentos na tese da eficácia ex tunc; resistência ao consequencialismo no período que se inicia com o agravamento do positivismo e do protoliberalismo do Código Tributário Nacional; adesão ao argumento de consequência pela Corte nomeada nos Governos de Fernando Henrique Cardoso e Luís Inácio Lula da Silva, em questões não-financeiras; e extensão do consequencialismo à matéria financeira (TORRES, 2010).

Iremos, a partir de agora, apresentar tais fases.

\subsection{1 - As primeiras resistências na tese da eficácia ex tunc}

A Constituição Federal regula a inconstitucionalidade das leis em vários dispositivos. Entre eles, podemos destacar o artigo 102, incisos I, a que atribui ao Supremo Tribunal Federal a competência para processar e julgar a Ação Direta de Inconstitucionalidade e III que estabelece situações em que lhe caberá julgar recurso extraordinário. ${ }^{15}$

Sendo a decisão de inconstitucionalidade proferida em qualquer um desses dois casos ou mesmo nas outras formas de controle de validade das leis e dos atos normativos, a doutrina brasileira, valendo-se dos ensinamentos da doutrina norte-americana clássica daí um dos motivos da importância de tal exposição prévia , sustentou, até mesmo na vigência das outras Constituições, que a declaração de inconstitucionalidade sempre tem efeitos ex tunc. Nesse sentido, encontramos a lição de Gilmar Ferreira Mendes:

\footnotetext{
O dogma da nulidade da lei inconstitucional pertence à tradição do Direito brasileiro. A teoria da nulidade tem sido sustentada por praticamente todos os nossos importantes constitucionalistas. Fundada na antiga doutrina americana, segundo a the inconstitucional statute is not law at all brasileira posicionou-se a favor da equiparação entre inconstitucionalidade e nulidade. (MENDES, 2009, p.1296)
}

Tal posicionamento, assim como aconteceu nos Estados Unidos, acabou sofrendo a influência de teorias que tinham o objetivo de conceder um maior equilíbrio entre tal

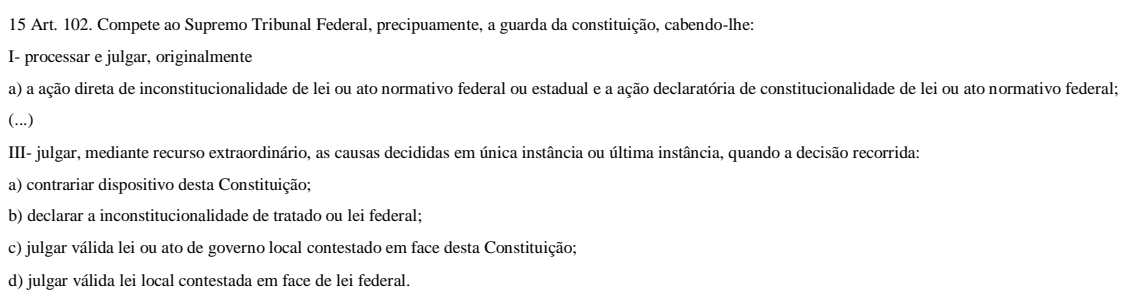


declaração de inconstitucionalidade e a validade e a eficácia da lei posteriormente a tal decisão.

O Supremo Tribunal Federal, ao analisar o Recurso Extraordinário n. 78.594, acabou declarando válido ato de Oficial de Justiça investido no cargo por lei que fora declarada inconstitucional em outra ação. Ou seja, mesmo com a declaração da inconstitucionalidade da lei (anteriormente proferida) que autorizou a designação do funcionário público, os atos praticados pelo agente permaneceram.

O relator do caso, Ministro Bilac Pinto, buscou sopesar os efeitos de uma declaração de inconstitucionalidade e os seus efeitos nos diversos casos. Nas palavras do julgador:

\footnotetext{
Os efeitos dessa declaração de inconstitucionalidade não podem ser sintetizados numa regra única, que seja válida para todos os casos.

A natureza civil ou penal de uma lei, por exemplo, tem importantes conseqüências na conceituação dos efeitos da declaração de inconstitucionalidade.

Esta observação revela que no estudo dessa matéria se deve ter em vista, de um lado, a inconstitucionalidade declarada e de outro a natureza da lei impugnada. ${ }^{16}$
}

Valendo-se de tais argumentos, além do fato de que a situação dos autos era de Direito Administrativo os quais deveriam ser observados também nos efeitos da declaração de inconstitucionalidade, Direito que estabelece o

como válidos, o relator observou que os efeitos da decisão não deveriam atingir as ações dos funcionários que agiram supor estar legalmente investidos. Além do mais, não teria a parte que alegara tal ilegalidade obtido qualquer prejuízo, vez que o princípio do contraditório, entre outros, fora observado.

Tal posicionamento foi reafirmado pela Corte tempos depois no julgamento do Recurso Extraordinário n. 79.343. O relator, Ministro Leitão de Abreu, firmou assim o seu entendimento:

\footnotetext{
Acertado se me afigura, também, o entendimento de que não se deve ter como nulo ab initio ato legislativo, que entrou no mundo jurídico munido de presunção de validade, impondo-se, em razão disso, enquanto não declarado inconstitucional, à obediência pelos destinatários dos seus comandos. Razoável é a inteligência, a meu ver, de que se cuida, em verdade, de ato anulável, possuindo caráter constitutivo a decisão que declara a nulidade. Como, entretanto, em princípio, os efeitos dessa decisão operam retroativamente, não se resolve, com isso, de modo pleno, a questão de saber se é mister haver como delitos do orbe jurídico atos ou fatos verificados em conformidade com a norma que haja sido pronunciada como inconsistente com a ordem constitucional. ${ }^{17}$
} 
Concluindo a questão, arremata o jurista:

\begin{abstract}
A tutela da boa fé exige que, em determinadas circunstâncias, notadamente quando, sob a lei ainda não declarada inconstitucional, se estabeleceram relações entre o particular e o poder público, se apure, prudencialmente, até que ponto a retroatividade da decisão, que decreta a inconstitucionalidade, pode atingir, prejudicando-o, o agente que teve por legítimo o ato e, fundado nele, operou na presunção de que estava procedendo sob o amparo do direito objetivo. ${ }^{18}$
\end{abstract}

Como se pode perceber, tal posição se assemelha muito àquela que era defendida por Hans Kelsen, trazendo-se para a questão de se saber quais os efeitos que devem ser dados a uma declaração de inconstitucionalidade, principalmente quando se propõe não à nulidade do ato, mas à sua anulabilidade.

Tal argumento, alinhado a um consequencialista, encontra respaldo no Supremo Tribunal Federal até mesmo em matéria tributária. Isso fica mais claro quando analisamos a uto pago indevidamente, quando reconhecido por decisão, que o contribuinte de jure não recuperou do contribuinte de facto o quantum

Em tais casos, o de se esperar é que a norma julgada inconstitucional tenha efeitos $e x$ tunc, podendo, com isso, o contribuinte de jure, sem nenhum empecilho, solicitar a repetição do indébito tributário. Ou seja, não haveria a necessidade de se provar que não repassou o encargo financeiro, pois, sendo a exação ilícita, nenhuma quantia deveria entrar nos cofres públicos. Essa, por ser indevida ao Fisco, retornaria àquele que a pagou. Também não poderia o montante ser incorporado ao patrimônio estatal, por lhe faltar o caráter legal.

No entanto, pelo conteúdo da súmula, não foi isso o que prevaleceu. As razões que motivaram tal entendimento podem ser encontradas, por exemplo, em voto do Ministro Victor Nunes Leal no Recurso Extraordinário n. 46.450. In verbis:

\footnotetext{
Seria menos justo proporcionar-lhe [ao contribuinte de direito] um sobrelucro sem causa, para seu proveito pessoal, do que deixar esse valor em poder do Estado, que presumivelmente já o teria aplicado na manutenção do serviços públicos e na satisfação dos encargos diversos que oneram o tesouro em benefício da coletividade. Se o dilema é sancionar um enriquecimento sem causa, quer a favor do Estado, com a carência ou improcedência da ação, quer em favor do contribuinte, se for julgado procedente o pedido, não há que hesitar; impõe-se a primeira alternativa, pois o Estado representa, por definição, o interesse coletivo, a cuja promoção se destina, no conjunto da receita pública, a importância reclamada pelo particular para sua fruição
}

${ }^{18}$ RE 79.343 
pessoal. Essa solução é que corresponde à equidade, fundamento básico da ação proposta. ${ }^{19}$

Como se pode notar, o argumento consequencialista aparece bem forte no acórdão citado (TORRES, 2010), bem como nas outras exposições. Veremos, a partir de agora, como foi a reação ao argumento da consequência na modulação de efeitos.

\subsubsection{Oposição do Supremo Tribunal Federal ao argumento da consequência}

Em lição trazida por Ricardo Lobo Torres (2010), o Supremo Tribunal Federal, durante as décadas de 1970 a 1990, foi bastante influenciado pelo positivismo apresentando raízes no Código Tributário Nacional , o que acabou firmando o entendimento na sua jurisprudência de que a declaração de inconstitucionalidade deveria ter eficácia ex tunc. Com isso, abandonava qualquer argumento baseado na consequência de que a decisão traria efeitos econômicos favoráveis ao contribuinte ou que causaria enorme déficit ao erário.

Nesse contexto, a Corte, ao apreciar a controvérsia que discutia a restituição da taxa de lixo criada por um decreto do Município do Rio de Janeiro o qual foi declarado inconstitucional e submetido a posterior generalização do julgado , decidiu no sentido de que se deveria restituir todos os valores indevidamente $\operatorname{cobrados}^{20}$.

Com relação a essa decisão, destacamos trecho do parecer apresentado pela Procuradoria-Geral da Justiça, o qual serviu como fundamento para voto do Ministro Oscar Corrêa, no qual se rebate o argumento de que permitir tal repetição de indébito implicaria enriquecimento sem causa em face dos municípios que prestaram o serviço:

\footnotetext{
Se, como se ressaltou, a simples atuação estatal nos casos de serviços públicos propriamente ditos não autoriza ou convalida a cobrança ou o pagamento do tributo, fazendo-se necessária a imposição da taxa através de lei, não se pode reconhecer ao Poder Público direito de retenção das importâncias indevidamente cobradas sob o fundamento de uma eventual prestação de serviço. Em verdade, reconhecer tal direito de retenção ao ente tributante é fazer tábua rasa do princípio da reserva legal. ${ }^{21}$
}

Tal julgado, portanto, vai ao encontro do que vem querendo se mostrar nesta parte. Outro $\operatorname{caso}^{22}$ que tem a mesma sorte é o de uma lei que alterou a alíquota do Imposto de Renda. Tal diploma faria com que incidisse uma alíquota maior do que a anterior em fatos geradores ocorridos antes da edição da lei. Essa incidência foi afastada pelo Supremo Tribunal Federal, fazendo com que, no caso, se mantivesse a alíquota anteriormente vigente.

\footnotetext{
${ }^{19}$ RE 46.450

${ }^{20} \mathrm{O}$ caso em comento é o RE 103.619.

${ }^{21}$ RE n. 103.619

${ }^{22}$ ADI 513.
} 
O julgamento em comento, mostrando-se em clara consonância com a Constituição Federal ${ }^{23}$, acabou afastando a antiga Súmula n. $584^{24}$, além de assegurar a eficácia ex tunc de tal decisão, rejeitando o argumento consequencialista de ameaça à solvência do tesouro. A respeito, destacamos o seguinte trecho da ementa da Ação Direta de Inconstitucionalidade n. 513:

\begin{abstract}
IV. Alegação de só poder ter efeito ex nunc decisão que nulifica lei que instituiu ou aumentou tributo auferido pelo Tesouro e já aplicado em serviços ou obras públicas. Sua inaplicabilidade à hipótese dos autos que não cogita, exclusivamente, de tributo já integrado ao patrimônio público, mas de ingresso futuro a ser apurado na declaração anual do contribuinte e recolhido posteriormente. Também não é ela atinente à eventual restituição de imposto pago a maior, porque está prevista em lei e terá seu valor reduzido pela aplicação de coeficiente menos gravoso.

V- Não existe ameaça iminente à solvência do Tesouro, à continuidade dos serviços públicos ou a algum bem política ou socialmente relevante, que justifique a supressão, in casu, do efeito próprio, no Brasil, do juízo de inconstitucionalidade da norma, que é a sua nulidade. É de repelir-se, portanto, a alegada ameaça de lacuna jurídica ameaçadora (bedrohliche Rechtslücke
\end{abstract}

A questão de se aplicar efeitos ex tunc à decisão de inconstitucionalidade ficou mais acirrada quando o tribunal analisou a questão da incidência da contribuição social sobre a

Ação Direta de Inconstitucionalidade n. 1.102

everia ter efeitos pro futuro, tal como se

observa dessa parte do voto:

Não pretendo, Sr. Presidente, a menos que a questão seja reavivada, voltar a discutir o que esta Corte já assentou em reiterados julgados no passado. Contudo, parece-me de inteira procedência a irresignação ministerial quanto aos efeitos retroativos que a Corte tem emprestado à declaração de inconstitucionalidade, principalmente, quando, como na espécie, os resultados consequiências da decisão impõe drásticas restrições ao orçamento da seguridade social, abalada por notória insuficiência de caixa.

Creio não constituir-se afronta ao ordenamento constitucional exercer a Corte política judicial de conveniência, se viesse a adotar a sistemática, caso a caso, para a aplicação de quais os efeitos que deveriam ser impostos, quando, como na hipótese, defluisse situação tal a recomendar, na salvaguarda dos superiores interesses do Estado e em razão da calamidade dos cofres da Previdência Social, se buscasse o

\footnotetext{
${ }^{23}$ Art. 150. Sem prejuízo de outras garantias asseguradas ao contribuinte, é vedado à União, aos Estados, ao Distrito Federal e aos Municípios:

I- Exigir ou aumentar tributo sem lei que o estabeleça;

(...)

III- Cobrar tributos

a) em relação a fatos geradores ocorridos antes do início da vigência da lei que os houver instituído ou aumentado;

b) no mesmo exercício financeiro em que haja sido publicada a lei que os instituiu ou majorou;

c) antes de decorridos noventa dias da data em que haja sido publicada a lei que os instituiu ou majorou, observado o disposto na alínea $b$;

${ }^{24}$ Súmula 584: Ao Imposto de Renda calculado sobre rendimentos do ano-base, aplica-se a lei vigente no exercício financeiro em que deve ser apresentada a declaração.

${ }^{25}$ ADI n. 513.
} 
dies a quo, para a eficácia dos efeitos da declaração de inconstitucionalidade, a data do deferimento cautelar. ${ }^{26}$

Em voto divergente, o Ministro Sepúlveda Pertence argumenta que admite a modulação dos efeitos, mas apenas em matérias em que efetivamente haja uma surpresa a uma das partes, o que não era verificado no caso em debate. In verbis:

O problema dramático da eficácia ex tunc da declaração de inconstitucionalidade vem a Suprema Corte a declara-lhe a invalidez de origem. Não é este o caso: a incidência da contribuição social sobre a remuneração de administradores, autônomos e avulsos vem sendo questionada desde a vigência da Lei 7.787, e creio que, nas vias do controle difuso, poucas terão sido as decisões favoráveis à Previdência Social.

(...)

Sou, em tese, favorável a que, com todos os temperamentos e contrafortes possíveis e para situações absolutamente excepcionais, se permita a ruptura do dogma da nulidade ex radice da lei inconstitucional, facultando-se ao Tribunal protrair o início da eficácia erga omnes da declaração. ${ }^{27}$

A divergência do voto do relator que acabou prevalecendo também é encontrada no voto do Ministro Marco Aurélio:

Compreendo as grandes dificuldades de caixa que decorrem do sistema de seguridade social pátrio. Contudo, estas não podem ser potencializadas, a ponto de colocar-se em plano secundário a segurança, que é o objetivo maior de uma Lei Básica, especialmente no embate cidadão-Estado, quando as forças em jogo exsurgem em descompasso. ${ }^{28}$

Apenas para encerrar os casos em que o tribunal ofereceu resistência aos efeitos prospectivos da decisão que declara a inconstitucionalidade de uma lei, convém mencionar o caso em que se discutia a legitimidade do aumento de alíquota do FINSOCIAL de 0,6 para 2\%, constante no Recurso Extraordinário n. 150.764.

Apesar de se ter em jogo uma questão delicada, que é o financiamento da saúde, a resolução da lide não chegou a envolver nenhum princípio sensível ou mesmo direitos e garantias fundamentais, restringindo-se mais à aplicação intertemporal e à hierarquia de normas.

Da acirrada discussão, destacamos o voto de desempate, proferido pelo Presidente à época, Ministro Sydney Sanches:

Não há possibilidade de se salvar o dispositivo, por mais nobre que seja o propósito interpretativo da Corte, ainda que para preservar o respeitabilíssimo interesse público do Tesouro, da Previdência e da Seguridade Social. Por mais nobre que seja esse interesse, não é possível sacrificar princípios intocáveis da Constituição, que,

\footnotetext{
${ }^{26}$ ADI n. 1.102

${ }^{27}$ ADI n. 1.102.

${ }^{28}$ ADI n. 1.102.
} 
também a meu ver, ficaram profundamente atingidos. Na verdade, o art. 56 do ADCT só existiu para dizer que, enquanto a lei não dispusesse sobre o art. 195, I, a arrecadação se faria do modo ali explicitado. ${ }^{29}$

Como se vê, a oposição do Ministro, no caso, foi contrária ao argumento consequencialista, pois, mesmo sabendo da importância de financiamento social da saúde, acabou decidindo de forma a reduzir tal orçamento.

Após tal exposição, analisaremos agora como a jurisprudência do Supremo Tribunal Federal voltou a admitir que o consequencialismo voltasse a influenciar na mitigação do efeito ex tunc nas decisões que declaram a inconstitucionalidade de uma norma.

\subsection{3 - O argumento da consequência em questões não-tributárias}

Primeiramente, deve-se chamar a atenção para o fato de que retorno para o retorno a uma teoria consequencialista. Antes de consistir em uma decisão pontual, a teoria fez parte de um processo com diversas etapas. Os primeiros passos podem ser observados a partir das mudanças legislativas durante a década de1990. Para uma melhor compreensão do fenômeno, vamos analisá-lo com mais detença.

\section{i) Alterações constitucionais e legislativas}

Como se procurou demonstrar, o STF, por um bom período, apresentou uma rígida orientação no sentido da preservação dos efeitos ex tunc da declaração de inconstitucionalidade, nos moldes da doutrina tradicional. Tal posicionamento, todavia, juntamente com as consequências inerentes que, de acordo com o que foi anteriormente aduzido, acabavam causando desfalques orçamentários, entre outros fatores , fizeram com que o legislador constituinte derivado ou ordinário passasse a se preocupar mais com a matéria, trazendo uma reação a tal doutrina.

Em um primeiro momento, promulga-se a Emenda Constitucional $n^{\circ} 3$, de 1993, que criou a Ação Declaratória de constitucionalidade de lei ou ato normativo federal, que hoje apresentam os mesmos efeitos da Ação Direta de Inconstitucionalidade. ${ }^{30}$

A sua relação com a questão em debate neste estudo é bem explicada por Ricardo Lobo Torres. Nas palavras do autor:

A ação declaratória de constitucionalidade, que não encontra paralelo de monta no direito comparado, tem endereço inequivocamente tributário, como se pode concluir da observação de que até hoje os poucos casos a que se aplicou versaram sobre a

${ }^{29}$ RE n. 150.764.

${ }_{30}$ Tribunal

Federal, nas ações diretas de inconstitucionalidade e nas ações declaratórias de inconstitucionalidade produziram eficácia contra todos e efeito vinculante, relativamente aos demais órgãos do Poder Judiciário e à administração pública direta e indireta, nas esferas federal, 
cobrança de tributos. Essa preocupação com a questão tributária surgiu exatamente do caos vivido pelo Judiciário nos anos imediatamente posteriores a 1988, com o acúmulo de ações sobre a inconstitucionalidade de diversas contribuições sociais, quase todas precedidas de depósito judicial para assegurar os mesmo efeitos econômicos da restituição, com incalculável prejuízo para a Fazenda Pública. (TORRES 2010, p.39)

Tal solução, na verdade, acabou se apresentando como um paliativo, pois não resolvia definitivamente o problema da eficácia temporal dos efeitos de uma decisão de inconstitucionalidade. De toda forma, criou-se mais um mecanismo para prevenir o Estado de não ser surpreendido pela decisão que declara a inconstitucionalidade de uma exação, circunstância que ensejaria graves consequências ao erário. Isso pode ser percebido a partir da declaração do Ministro Sepúlveda Pertence, quando do julgamento da Ação Direta de Inconstitucionalidade n. 1.102:

Por outro lado, para situações como a desta lei, cuja constitucionalidade foi objeto de discussão judicial desde o início, a Emenda Constitucional $\mathrm{n}^{\circ} 3$ já dotou o Executivo de um mecanismo hábil a não ser o fisco surpreendido, muito tempo depois, por uma declaração de sua validade ou invalidade com eficácia erga omnes: é a ação declaratória de inconstitucionalidade. ${ }^{31}$

O ajuizamento de tal ação teria o condão de evitar qualquer grave ameaça ao orçamento, conservando-se, ainda, o Estado de Direito.

Após tal modificação, outras ações foram tentadas, mas sem muito sucesso. A grande modificação surge com a edição da Lei 9.868/99, que trouxe, afinal, a previsão expressa da possibilidade de modulação dos efeitos da decisão que declara a inconstitucionalidade de uma lei:

Art. 27. Ao declarar a inconstitucionalidade de lei ou ato normativo, e tendo em vista razões de segurança jurídica ou de excepcional interesse social, poderá o Supremo Tribunal Federal, por maioria de dois terços de seus membros, restringir os efeitos daquela declaração ou decidir que ela só tenha eficácia a partir de seu trânsito em julgado ou de outro momento que venha a ser fixado.

Vale a pena notar que o nosso dispositivo encontra inspiração em artigo da Constituição Portuguesa:

Artigo 282.

Efeitos da declaração de inconstitucionalidade ou de ilegalidade

1. A declaração de inconstitucionalidade ou de ilegalidade com força obrigatória geral produz efeitos desde a entrada em vigor da norma declarada inconstitucional

\footnotetext{
${ }^{31}$ ADI n. 1.102 .
} 
ou ilegal e determina a repristinação das normas que ela, eventualmente, haja revogado.

2. Tratando-se, porém, de inconstitucionalidade ou de ilegalidade por infracção de norma constitucional ou legal posterior, a declaração só produz efeitos desde a entrada em vigor desta última.

3. Ficam ressalvados os casos julgados, salvo decisão em contrário do Tribunal Constitucional quando a norma respeitar a matéria penal, disciplinar ou de ilícito de mera ordenação social e for de conteúdo menos favorável ao arguido.

4. Quando a segurança jurídica, razões de equidade ou interesse público de excepcional relevo, que deverá ser fundamentado, o exigirem, poderá o Tribunal Constitucional fixar os efeitos da inconstitucionalidade ou da ilegalidade com alcance mais restrito do que o previsto nos n. ${ }^{\circ} \mathbf{1}$ e 2 . (grifos nossos)

Esse artigo 27 da Lei 9.868/99 foi o responsável por, paulatinamente, alterar aquele entendimento do STF que rejeitava a possibilidade de aplicação de efeitos prospectivos às suas decisões. Vamos ver agora como a Corte mudou tal entendimento.

\section{ii) a aplicação do artigo 27 da Lei 9.868/99 em matérias não-tributárias}

Em um primeiro momento, o artigo 27 da Lei 9.868/99 não foi aplicado, chegando a ter a sua constitucionalidade questionada. ${ }^{32}$ Apesar de sabermos que até o momento a questão não foi decidida de forma definitiva pelo Pretório Excelso, cremos que o Tribunal não declarará que a norma padece de vício ${ }^{33}$ porque frequentemente vem sendo utilizada. Nesse mesmo sentido, encontramos o pronunciamento do Ministro Gilmar Mendes na Ação Direta de Inconstitucionalidade n. 2.240:

É certo que o Supremo Tribunal Federal ainda não se pronunciou definitivamente sobre a constitucionalidade do art. 27 da Lei ${ }^{\circ}$ 9.868/99. É notório, porém, que o Tribunal já está a aplicar o art. 27 aos casos de controle incidental e controle abstrato. Desse modo, parece superado o debate sobre a legitimidade da fórmula positivada no referido artigo. ${ }^{34}$

De todo modo, a jurisprudência do Supremo aos poucos foi se preocupando com a flexibilização dos efeitos das suas decisões, passando, no decorrer do tempo, a aceitar a aplicação do diploma referido mais especificamente, após a mudança de composição do Tribunal a partir de 2003, na lição de Ricardo Lobo Torres (2010), ou a partir da passagem do homem político Nelson Jobim pela Corte, nos dizeres de Fábio Martins de Andrade (2010).

\footnotetext{
${ }_{33}^{32}$ As Ações Diretas de Inconstitucionalidade n. 2.154 e 2.258 põem em xeque tal dispositivo.

33. data

venia, o argumento segundo o qual o poder atribuído ao Supremo Tribunal Federal de regular os efeitos das decisões proferidas no bojo de ações de natureza objetiva, em particular o seu efeito temporal, não se encontra previsto em nenhum dispositivo constitucional. É que o Supremo, segundo o artigo 102, caput $\quad$-se de um múnus de matiz político, cujo exercício comporta considerável margem de discricionariedade, exatamente para que a Corte possa dar efetividade ao princípio da supremacia Constitucional

${ }^{34}$ ADI n. 2.240
} 
De todo modo, tal mudança se deu em grande parte pela influência do argumento consequencialista nos efeitos das decisões.

Com isso, questões não financeiras tiveram decisões com efeitos diferidos no tempo. A título exemplificativo, podemos citar o caso da fidelidade partidária ${ }^{35}$ em que o Tribunal fixou que só perderiam o cargo aqueles políticos que mudaram de partido após a decisão do Tribunal Superior Eleitoral e da criação de município de forma incompatível com a Constituição $^{36}$ aqui o Tribunal declarou a inconstitucionalidade sem a pronúncia da nulidade, assegurando um lapso temporal suficiente para que a criação do município pudesse ser reapreciada pelo legislador estadual.

Tal questão, não muito tempo depois, acabou atingindo matérias de Direito Tributário. Esse tema será estudado com mais profundidade em capítulo específico. Antes disso, far-se-á uma análise dos elementos estruturantes do Estado de Direito, conceito que fornecerá bons subsídios para o estudo crítico da jurisprudência do Supremo Tribunal Federal. 


\section{2 - O Estado de Direito}

Sem o intuito de querer esmiuçar o momento histórico que propiciou o surgimento do Estado de Direito, ou mesmo de suas diferentes experiências históricas ${ }^{37}$, importa para esse trabalho demonstrar como o seu conceito e a sua sujeição são de fundamental importância para a solução da questão de como e quando o Supremo Tribunal Federal deve conferir efeitos prospectivos às suas decisões, especialmente em lides envolvendo Direito Tributário.

Todavia, convém deixar registrado que o conceito de Estado de Direito está invariavelmente atrelado ao momento em que o próprio Estado passa a se submeter a leis por ele criadas, mas mais do que isso: essa restrição tem o objetivo de resguardar os direitos individuais. Danilo Zolo, sintetizando as diferentes manifestações do instituto, aponta o seguinte:

Neste sentido, o Estado de Direito é uma versão do Estado moderno europeu, na qual, com base em específicos pressupostos filosófico-políticos, atribui-se ao ordenamento jurídico a função de tutelar os direitos subjetivos, contrastando a tendência do poder político de dilatar-se, de operar de modo arbitrário e prevaricar. (ZOLO, 2006, p. 31)

A partir de tal reserva, não se permite mais ao Estado atuar sem moderação, devendo somente operar conforme a lei, assegurando-se a sua atuação de forma a preservar os direitos individuais.

Tal informação, no entanto, é insuficiente para entendermos a importância do instituto no objeto de estudo deste trabalho. Dessa forma, valendo-nos da lição de José Joaquim Gomes Canotilho, buscaremos apresentar os requisitos mais importantes do Estado de Direito. Nos dizeres do constitucionalista, alguns elementos seriam os pilares do instituto:

Independentemente das densificações e concretizações que o princípio do Estado de direito encontra implícita ou explicitamente no texto constitucional, é possível sintetizar os pressupostos materiais subjacentes a este princípio da seguinte forma: (1) juridicidade; (2) constitucionalidade; (3) direitos fundamentais. (CANOTILHO, 1992, p. 361)

É imperioso analisar cada um desses pontos.

${ }^{37}$ ZOLO (2006, p. 11-30). O autor aponta que as principais experiências históricas seriam principalmente quatro: a experiência do Rechtsstaat alemão; a do rule of law inglês; a importante variante do rule of law americano; e o État dedroit francês. 


\title{
2.1 - Juridicidade
}

Quando se pensa no princípio do Estado de Direito, estamos tratando de um preceito que procura, de forma constitutiva, material, procedimental e formal, apresentar resposta ao problema do conteúdo e extensão em que o Estado pode proceder a sua atividade. O Estado de Direito tem como objetivo conformar as estruturas do poder político e a organização do estado de acordo com a medida do direito.

Esse direito apresenta-se de forma racional e vinculativa, coordenando a organização de uma comunidade. Para tanto, criam-se regras e fixam-se procedimentos, cunhando instituições que os velarão (CANOTILHO, 1992).

Essas criações são de importância ímpar. Isso é evidente quando observamos a lição de Canotilho:

\begin{abstract}
Articulando medidas ou regras materiais com formas e procedimentos, o direito é, simultaneamente, medida material e forma da vida colectiva (K. Hesse). Forma e conteúdo pressupõem-se reciprocamente: como meio de ordenação racional, o direito é indissociável de realização da justiça, de efectivação de valores políticos, económicos, sociais e culturais; como forma, ele aponta para a necessidade de garantias jurídico-formais, de modo a evitar acções e comportamentos dos poderes públicos, arbitrários e irregulares. (CANOTILHO, 1992, p. 362)
\end{abstract}

Nesse contexto, a ordenação estabelecida pelo Direito apresenta uma conexão entre as dimensões objetiva e subjetiva, de forma que, mesmo estabelecendo padrões de conduta, garante-se uma distanciação do indivíduo do Direito. Dessa forma, o Estado de Direito seria uma forma de Estado da distância, na medida em que garante os indivíduos perante o Estado e perante outros indivíduos, além de lhes garantir um espaço irredutível de autonomia, este marcado pela diferença e individualidade (CANOTILHO, 1992).

Após essas considerações, convém analisar a próxima característica.

\section{2 - Constitucionalidade}

Hodiernamente, o Estado de Direito é um Estado Constitucional (CANOTILHO, 1992), ou seja, é uma organização político-administrativa que implica a existência de uma constituição que sirva de base jurídico-normativa. A função da constituição no ordenamento jurídico é elucidada por Gomes Canotilho:

A constituição confere à ordem estadual e aos actos dos poderes públicos medida e forma. Precisamente por isso, a lei constitucional não é apenas como sugeria a teoria tradicional do Estado de direito uma simples lei incluída no sistema ou no complexo normativo-estadual. Trata-se de uma verdadeira ordenação normativa fundamental dotada de supremacia supremacia da constituição e é nesta 
supremacia normativa da lei constitucional que o $\langle\langle$ primado do direito $\rangle$ do Estado de direito encontra uma primeira e decisiva expressão. (CANOTILHO, 1992, p. 364)

O tema também foi desenvolvido por Hans Kelsen, que, analisando a hierarquia de normas existente, assentava a sua base na norma fundamental hipotética, mas elevava a constituição como condição de existência e validade de todas outras normas. In verbis:

Se começarmos levando em conta apenas a ordem jurídica estadual, a Constituição representa o escalão de Direito Positivo mais elevado. A Constituição é aqui entendida num sentido material, quer dizer: com esta palavra significa-se a norma positiva ou as normas positivas através das quais é regulada a produção das normas jurídicas gerais. (KELSEN, 2006, p. 247)

Como se pode perceber, disso se infere a supremacia da Constituição. Esse tema é comentado por Gilmar Mendes:

Noutras palavras, pela sua própria localização na base da pirâmide normativa, é a Constituição a instância de transformação da normatividade, puramente hipotética, da norma fundamental, em normatividade concreta, dos preceitos de direito positivo comandos postos em vigor cuja forma e conteúdo, por isso mesmo, subordinam-se aos ditames constitucionais. Daí se falar em supremacia constitucional formal e material, no sentido de que qualquer ato jurídico seja ele normativo ou de efeito concreto, para ingressar ou permanecer, validamente, no ordenamento, há de mostrar conforme aos preceitos da Constituição. (MENDES, 2009, p.14-15)

Assim, a localização da Constituição na base do ordenamento jurídico faz com que todos os atos tenham validade, ao menos em último lugar, nela. Assim, uma lei só é válida porque foi editada nos moldes e com o conteúdo que a Constituição estabelece. Um decreto do poder executivo ou uma decisão judicial retira a sua validade em uma lei, que tem sua validade somente se obedece ao quanto prescrito pela Constituição. Disso se extrai o os seguintes elementos constitutivos do princípio do Estado de Direito: a vinculação do legislador à Constituição (CANOTILHO, 1992) do ponto de vista formal e material como o que determina a vinculação de todos os restantes atos do Estado à Constituição (CANOTILHO, 1992).

Diante de tais constatações é que surge a concepção de estrutura escalonada das normas jurídicas (KELSEN 2006), formando uma estrutura cuja base repousa na Constituição. Nesse sentido, temos os ensinamentos de Carlos Ari Sundfeld:

Por isso o ordenamento jurídico é uma pirâmide: o ato administrativo e a sentença valem se estiverem de acordo com a lei, que lhes é superior; a lei vale se estiver de 
acordo com a Constituição, que lhe é superior. Olhando no sentido inverso, verificamos que a Constituição é o fundamento de validade de todas as normas do ordenamento jurídico. Nisso consiste a supremacia da Constituição. (SUNDFELD, 2006, p. 40)

Tal imperativo se torna ainda mais necessário quando há violação de direitos fundamentais. Essa preocupação já era externada por Kelsen:

\begin{abstract}
A Constituição, que regula a produção de normas gerais, pode também determinar o conteúdo das futuras leis. E as Constituições positivas não raramente assim procedem ao prescrever ou ao excluir determinados conteúdos.

(...)

O catálogo de direitos e liberdades fundamentais, que forma uma parte substancial das modernas constituições, não é, na essência, outra coisa senão uma tentativa de impedir que tais leis venham a existir. É eficaz quando pelo estabelecimento de tais leis v.g., leis que violem a chamada liberdade da pessoa ou de consciência, ou a igualdade se responsabiliza pessoalmente determinado órgão que participa na criação dessas leis chefe do Estado, ministros ou existe a possibilidade de as atacar e anular. Tudo isso sob o pressuposto de que a simples lei não tenha força para derrogar a lei constitucional que determina a sua produção e o seu conteúdo, de que esta lei somente possa ser modificada ou revogada sob condições mais rigorosas, como sejam uma maioria qualificada ou um quorum mais amplo. Quer isto dizer que a Constituição prescreve para a sua modificação ou supressão um processo mais exigente, diferente do processo legislativo usual; que, além da forma legislativa, exige uma específica forma constitucional. (KELSEN, 2006, p. 249)
\end{abstract}

Canotilho aduz que outro elemento constitutivo do Estado de Direito seria o princípio da reserva da Constituição, o qual se amolda justamente a essa preocupação externada por Kelsen. Segundo o constitucionalista português, a reserva de Constituição teria uma consequência dupla: os órgãos do Estado só podem fazer aquilo que a Constituição lhes permite e, quando em jogo direitos, liberdades e garantias individuais, fica estabelecido que restrições a tais direitos devem ser feitas diretamente pela Constituição ou por meio de lei, mediante autorização expressa e nos casos expressamente por ela previstos (CANOTILHO, 1992).

A função de tal exigência é clara: sujeitar o Estado à ordem jurídica. Com isso, uma norma jurídica que o criou regula a sua atuação, de forma a evitar a superposição de normas por ele mesmo criadas às suas intenções iniciais. Mostrando uma síntese histórica acerca do tema, temos a lição de Norberto Bobbio:

No plano histórico, sustento que a afirmação dos direitos do homem deriva de uma radical inversão de perspectiva, característica da formação do Estado Moderno, na representação da relação política, ou seja, na relação Estado/cidadão ou soberano/súditos: relação que é encarada, cada vez mais, do ponto de vista dos direitos dos cidadãos não mais súditos, e não do ponto de vista dos direitos do soberano, em correspondência com a visão individualista da sociedade, segundo a qual, para compreender a sociedade, é preciso partir de baixo, ou seja, dos 
indivíduos que a compõem, em oposição à concepção orgânica tradicional, segundo a qual a sociedade como um todo vem antes dos indivíduos. (BOBBIO, 2004, p.24)

A inversão tratada por Bobbio, segundo Gilmar Mendes, foi de fundamental importância para a concretização dos direitos fundamentais, ocasião em que o indivíduo passa a ter primeiro direitos em relação ao Estado, e, após, deveres, além de que os direitos obtidos pelo Estado se coordenam de forma a propiciar da melhor forma possível as necessidades e os direitos dos cidadãos (MENDES, 2009).

Apenas para encerrar tal abordagem, é válido explicitar que as consequências que tal princípio traz são enormes, pois, caso uma norma não esteja em conformidade com a Constituição, ela deverá ser considerada inconstitucional. Por lhe faltar o requisito da validade, ela não pode, nem deve, ser acatada. Como tal assunto foi devidamente estudado, convém apenas aduzir a lição de Maria Garcia, que entrelaça as duas questões:

\begin{abstract}
A questão do controle de constitucionalidade, decorrente da rigidez constitucional, ampara-se fundamentalmente no princípio da supremacia da Constituição que dá existência ao pacto fundacional, pelo que a Constituição situa-se no ápice do ordenamento jurídico, dando a este unidade política e coerência sistemática.

São, assim, os dois primeiros instrumentos básicos da defesa da Constituição: o controle difuso, sob a égide do princípio democrático e o controle concentrado, em atendimento ao princípio da supremacia constitucional. (GARCIA, 2010, p.212)
\end{abstract}

\title{
2.3 - Sistema de direitos fundamentais
}

A nossa Constituição Federal estabelece que um dos fundamentos que regem a nossa República é a dignidade da pessoa humana ${ }^{38}$. Para efetivar tal princípio, estabeleceu-se uma série de direitos, liberdades e garantias, que são encontradas ao longo do texto constitucional. A reserva de tais direitos tem como raiz antropológica a recondução do homem como pessoa, como cidadão, como trabalhador e como administrado.

José Joaquim Gomes Canotilho, ao se deparar com o problema do conceito de tais direitos fundamentais, propõe uma integração pragmática de tal conceito, reduzindo-o a cinco enunciados:

(1) Afirmação da integridade física e espiritual do homem como dimensão irrenunciável da sua individualidade autonomamente responsável (CRP, arts. $\left.24 .^{\circ}, 25 .^{\circ}, 26 .^{\circ}\right)$

\footnotetext{
${ }^{38}$ Art. $1^{\circ}$ A República Federativa do Brasil, formada pela união indissolúvel dos Estados e Municípios e do Distrito Federal, constitui-se em Estado Democrático de Direito e tem como fundamentos:

(...)

III - a dignidade da pessoa humana;
} 
(2) Garantia da identidade e integridade da pessoa através do livre desenvolvimento da personalidade (cfr. Refracção desta ideia no art. 73/2. ${ }^{\circ}$ da CRP).

(3) Libertação da < < angústia da existência >> da pessoa mediante mecanismos de sociabilidade, dentro os quais se incluem a possibilidade de trabalho e a garantia de condições existenciais mínimas (cfr. CRP, arts. 53..$^{\circ}$ 58. $.^{\circ} 63 .^{\circ}, 64 .^{\circ}$ )

(4) Garantia e defesa da autonomia individual através da vinculação dos poderes públicos a conteúdos, formas e procedimentos do Estado de Direito.

(5) Igualdade dos cidadãos, expressa na mesma dignidade social e na igualdade de tratamento normativo (igualdade perante a lei) Cfr. CRP, art13. . (CANOTILHO, 1992, p.367)

Tal definição seria adequada às alusões normativas da nossa Constituição, além de -judicialmente controláveis (CANOTILHO,

1992, p.368).

\section{4 - Separação dos Poderes}

José Joaquim Gomes Canotilho aduz que as três dimensões abordadas juridicidade, constitucionalidade e direitos fundamentais conduzem à noção de que o princípio do Estado de Direito apresenta duas ideias ordenadoras:

(1) Ideia de ordenação subjectiva, garantindo um status jurídico aos indivíduos essencialmente ancorado dos direitos fundamentais.

(2) Ideia de ordenação objectiva, assente no princípio da constitucionalidade, que, por sua vez, acolhe como princípio objectivamente estruturante, o princípio da divisão de poderes. (CANOTILHO, 1992, p. 368)

O autor enfatiza que tais conceitos não chegam a ser totalmente desassociados, e que o seu estudo vai ser basicamente com relação à ordenação objectiva . O presente trabalho, no entanto, prefere subdividir o assunto, analisando, ainda que sucintamente, a ordenação subjectiva .

\section{i) Ordenação subjectiva}

Partindo da ideia de que o ordenamento garante um status jurídico aos indivíduos, que repousa na concepção de direitos fundamentais, Canotilho conclui que todos os elementos do Estado de direito têm o objetivo de proteger a esfera jurídico-subjetiva dos indivíduos (CANOTILHO, 1992). Nesse sentido, também temos Carlos Ari Sundfeld:

A proteção do indivíduo contra o Estado é o objetivo de toda a magistral construção jurídica que percorremos. Nada mais natural, portanto, que o direito público por inteiro esteja embebido desta preocupação última, que exala desde a Constituição até a mais ínfima das normas. (SUNDFELD, 2006, p.48) 
Não é por menos que José Afonso da Silva (1989) ressalta que as constituições têm

teoria da supremacia constitucional, revelam que existe um núcleo de direitos humanos que são estabelecidos em tal texto e, por lá estarem, não podem ser suprimidos pela atuação estatal, nem mesmo por leis. Evidentemente, atualmente é certo que não podemos considerálos absolutos em todas as hipóteses, ignorando a impossibilidade de conflito de um direito fundamental com outro, ambos com status constitucional. ${ }^{39}$ Ademais, a evolução histórica pode conduzir à limitação ou à modificação de conteúdo de determinado direito.

Por não poderem ser alterados substancialmente, tais direitos fundamentais serão norteadores da atividade estatal. Aliás, essa posição dentro da constituição apresenta uma importância fundamental para a máxima eficácia das limitações estatais à liberdade dos indivíduos.

\section{ii) Ordenação objectiva}

José Joaquim Gomes Canotilho expõe que a teoria constitucionalista mais recente aponta que o princípio da separação de poderes apresenta duas dimensões complementares: a separação como uma forma de divisão, controle e limite do poder; e a separação como constitucionalização, ordenação e organização do poder estatal como forma de termos decisões funcionalmente eficazes e materialmente justas (CANOTILHO, 1992).

As razões para a adoção da primeira dimensão podem ser encontradas nas palavras de um dos principais idealizadores de tal sistema: Charles de Montesquieu. In verbis:

de limites.

puisse abuser du pouvoir, il faut que, par la disposition des choses, le pouvoir arrête le pouvoir. ${ }^{40}$ (MONTESQUIEU, 1927, p. 151)

E arremata o autor:

Lorsque dans la même personne ou dans le même corps de magistrature, la puissance législative est réunie

tyrannique pour lês exécuter tyranniquement.

ée de la

le pouvoir sur la vie et la liberté des citoyens seroit arbitraire: car le juge seroit

\footnotetext{
${ }_{40}^{39}$ A respeito do tema, MENDES, 328 s.s.

m que tem o poder tende a abusá-lo; ele vai até onde encontra
limites. Quem o diria! A própria virtude tem necessidade de limites. Para que não se possa abusar do poder é preciso que, pela disposição das coisas, o poder detenha o poder .
} 
législateur. Si elle étoit jointe à la puissance exécutrice, le juge pourroit avoir la

41 (MONTESQUIEU, 1927, p. 152).

Cada poder, exercendo uma função política específica, com independência com relação aos demais de forma tal que uma autoridade de um poder não deve respeito hierárquico às autoridades do outro faria com que um poder freasse a atuação do outro, evitando-se a tirania (SUNDFELD, 2006).

Evidentemente, não se desconhece que tal formulação, hodiernamente, não permanece tão forte quanto na época do Iluminismo, exigindo do intérprete uma compreensão constitucionalmente adequada. Exemplos disso não faltam. Entre eles, encontramos a legislação judicial, consequência da inevitável atuação de juízes e tribunais, em especial nas cortes constitucionais, onde com frequência se tem a criação de normas de caráter geral, como as chamadas sentenças aditivas proferidas no controle de constitucionalidade (MENDES, 2009).

Mas será que tal atuação não viola mesmo a separação dos poderes? Ou será que não encontra limites? Tal questão é suscitada por Manoel Gonçalves Ferreira Filho:

É notório que a fórmula clássica há muito está superada e certamente não quis a Lei Magna segui-la, como fica claro, por exemplo, na previsão de medidas provisórias. Entretanto, é de se perguntar se o judiciário pode legitimamente impor ações e políticas ao Executivo, sem levar em conta os parâmetros a que este está constitucionalmente submetido, como cláusulas orçamentárias e limites de despesas. Ou se ele pode regular matérias quando o Poder competente não o fez, quiçá por omissão, quiçá por causa de sua inoportunidade, ou em que medida o pode fazer. (FERREIRA FILHO, 2008, p. 90.)

Continuando a crítica, o autor aponta que o Judiciário, por não ter seus membros eleitos para exercer o papel político, não teria a legitimidade democrática referida na Constituição (FERREIRA FILHO, 2008). O jurista ainda argumenta que tal atuação pode levar a uma politização do Judiciário:

Acostumando-se a decidir questões políticas, o Judiciário, melhor os Juízes, podem ceder à tentação de suprir com suas liminares ou julgamentos a atuação dos demais Poderes, vistos como omissos ou corruptos. É o ativismo judicial que não está ausente do Brasil atual.

Ademais, por decidir questões políticas, o Judiciário pode-se politizar, assumindo ele próprio viés ideológico. (FERREIRA FILHO, 2008, p.90) Poder Legislativo, o poder sobre a vida e a liberdade dos cidadãos seria arbitrário, pois o juiz seria legislador. Se ele estiver confundido com o Poder E 
Após essa exposição em que se abordou, na visão de Canotilho, os pressupostos materiais subjacentes ao princípio do Estado de Direito a saber: juridicidade, constitucionalidade, direitos fundamentais e separação dos poderes, passaremos a estudar alguns subprincípios que o concretiza, ainda de acordo com a visão do constitucionalista português.

\title{
2.5 - Os subprincípios concretizadores do Estado de Direito
}

\subsection{1 - Princípio da legalidade da administração}

A conceituação de tal mandamento lógico é feita por Canotilho:

\begin{abstract}
O princípio da legalidade da administração, sobre o qual insistiu sempre a teoria do Estado de direito e a doutrina da separação de poderes e que acabou por ser considerado mesmo como o seu <<cerne essencial〉>, postulava, por sua vez, dois princípios fundamentais: o princípio da supremacia ou prevalência da lei (Vorrang des Gesetzes) e o princípio da reserva de lei (Vorbehalt des Gesetzes). Estes princípios permanecem válidos, pois num Estado democrático-constitucional a lei parlamentar é, ainda, a expressão privilegiada do princípio democrático (daí a sua supremacia) e o instrumento mais apropriado e seguro para definir os regimes de certas matérias (sobretudo dos direitos fundamentais). (CANOTILHO, 1992, p.375)
\end{abstract}

Tendo em vista a importância de tal subprincípio, convém estudá-lo com maior detença.

Carlos Ari Sundfeld (2006) aponta que a lei, durante o período medieval, apresentava a característica de ser sagrada e imutável e, no absolutismo, representava a manifestação do soberano indivíduo que ostentava um querer divino. Isso deixa de existir a partir do desenvolvimento do Estado de Direito, ocasião em que a lei passa a ter uma característica humana, sendo a expressão de uma vontade geral. Por estar destinada a comandar as condutas dos homens, deve por eles ser feita.

Um dos principais teóricos de tal transformação foi Jean-Jaques Rousseau. A respeito, destacamos o seguinte trecho:

As leis não são, em verdade, senão as condições da associação civil. O povo submetido às leis deve ser o autor delas; somente aos que se associam compete regulamentar as condições da sociedade. (ROUSSEAU, 2006, p.48)

Já que a lei é a expressão da vontade geral, o Estado também deverá se sujeitar a ela, condicionando suas ações, tais como atos administrativos e sentenças. Com isso, temos uma hierarquia entre a lei e esses atos. 
Percebe-se que tal formulação é indissociável da teoria desenvolvida no capítulo anterior a da separação dos poderes e vice-versa: a superioridade da lei não funciona sem a separação dos poderes e esta não é possível sem a superioridade da lei (SUNDFELD, 2006).

A Administração Pública e o Judiciário, ao exercerem as suas funções, devem aplicar a lei, que é a concretização da vontade geral. Deixam-se de lado, com isso, os anseios pessoais que poderiam interferir no caso concreto.

A extensão do aludido princípio é bem exposta por Gilmar Mendes:

Quanto ao princípio da legalidade, significa, nos termos do art. $5^{\circ}$, inciso II, da nossa Constituição, que ninguém será obrigado a fazer ou deixar de fazer alguma coisa senão em virtude de lei, um preceito multifuncional cujo núcleo essencial se espraia e se especifica no âmbito do ordenamento jurídico, dando origem a múltiplas expressões processo legislativo, devido processo legal, incidência da lei, retroatividade e ultra-atividade da lei, repristinação da lei, lacunas da lei, legalidade administrativa, legalidade penal e legalidade tributária, entre ouras as quais, embora distintas em sua configuração formal, substancialmente traduzem uma só e mesma idéia, a de que a lei é o instrumento por excelência de conformação jurídica das relações sociais. (MENDES, 2009, p. 180)

O princípio da legalidade, tal como acima aduzido, é especificamente resguardado em matéria tributária. ${ }^{42}$ Tal questão é bem sintetizada nas palavras de José Eduardo Soares de Melo:

O ordenamento jurídico contempla a reserva formal de lei, mediante a fixação precisa e determinada do órgão titular competente para sua expedição; e a reserva material da lei com a característica de ordem abstrata, geral e impessoal.

A instituição, majoração e extinção de tributos (art. 150, I, III, $a$ e $b$, da Constituição), bem como os casos de subsídio, isenção, redução de base de cálculo, concessão de crédito presumido, anistia ou remissão, relativos a impostos, taxas ou

como espécie normativa editada pelo Poder Legislativo (excepcionalmente pelo Poder Executivo, nos casos de medidas provisórias, previstas no art. 62 da Constituição), contendo preceitos vinculantes. (MELO, 2008, p. 18-19)

No Direito Tributário, a superioridade da lei também assume múltiplos significados: somente a lei pode criar, extinguir, majorar ou reduzir tributos (SABBAG, 2009) princípio da legalidade estrita; a instituição ou a majoração de tributos só podem incidir sobre fatos que passam a existir após sua vigência (MELO, 2008) princípio da anterioridade; e a vedação da

\footnotetext{
${ }^{42}$ Art. 150. Sem prejuízo de outras garantias asseguradas ao contribuinte, é vedado à União, aos Estados, ao Distrito Federal e aos Municípios:

I - exigir ou aumentar tributo sem lei que o estabeleça;

(...)

III - cobrar tributos:

a) em relação a fatos geradores ocorridos antes do início da vigência da lei que os houver instituído ou aumentado

b) no mesmo exercício financeiro em que haja sido publicada a lei que os instituiu ou aumentou;

c) antes de decorridos noventa dias da data em que haja sido publicada a lei que os instituiu ou aumentou, observado o

disposto na alínea b;
} 
cobrança de tributos antes de decorridos 90 dias (SABBAG, 2009) princípio da anterioridade nonagesimal.

Apesar de não se desconhecer que existem mitigações para a superioridade da lei (tais como a possibilidade de se alterar alíquotas de tributos por decreto), deve-se ressaltar que tais hipóteses encontram-se previstas no texto constitucional, demonstrando que tais exceções representam algo raro, que deve ser regulado igualmente por dispositivo da Lex Legum, mais infensa a alterações ocasionais, fato que demonstra o cuidado que se deve ter com tal relativização de princípio.

De toda a forma, quando se pensa na superioridade da lei, tem-se em mente que, como a tributação é uma forma de invasão do Estado no patrimônio de um particular, é prudente, e até necessário, que isso ocorra de acordo com a vontade popular (SABBAG, 2009). Representa lei $\mathrm{p}$

interferências estatais diversas da lei. Para encerrar o tema, temos as palavras de José Eduardo Soares de Melo:

O princípio da legalidade consubstancia os valores de certeza e segurança jurídica, sendo o vetor dos vetores, princípio constitucional carregado de carga valorativa, de transcendental importância ao Estado de Direito, e atina, também e sobretudo, à imunização dos administrados contra as próprias leis; coarta a discricionaridade do legislador. (MELO, 2008, p. 19)

\subsection{2 - Os princípios da segurança jurídica e da proteção da confiança dos cidadãos}

Além dos outros elementos do Estado de Direito anteriormente aduzidos, entendemos que os princípios da segurança jurídica e da proteção da confiança dos cidadãos, na linha do quanto abordado por José Joaquim Gomes Canotilho (1992), apresentam-se como verdadeiros direitos fundamentais do nosso ordenamento jurídico, porque, como a ideia central de tal sistema cinge-se na proteção dos indivíduos contra desmandos estatais, a previsibilidade de atuação do Estado deve fazer parte de seus pilares estruturantes.

Para melhor concretização de tais direitos, os particulares devem ser capazes de saber com previsibilidade e antecedência os moldes da atuação estatal que será responsável por interferir na sua esfera de liberdade, de forma a que lhes seja assegurado o mínimo de segurança para que possam conduzir, planificar e conformar de forma autônoma e responsável as suas vidas (CANOTILHO, 1992).

Apesar de nossa Constituição não fazer referência expressa a um dispositivo nesse sentido, não se pode ignorar que existem menções implícitas, tal como pode ser observado a 
partir da análise do artigo $5^{\circ}$, II o princípio da legalidade, já abordado e XXXVI ${ }^{43}$, e 150, III $^{44}$ também mencionados.

A segurança jurídica e a proteção dos cidadãos, além de se apresentarem como direitos fundamentais, devem ser encaradas como elementos de justificação e de integração do próprio Estado de Direito, que não pode ser idealizado sem tais componentes.

Ainda com relação a tais princípios, com arrimo nos ensinamentos de Canotilho, podemos estabelecer as suas principais balizas:

\begin{abstract}
Os princípios da protecção da confiança e da segurança jurídica podem formular-se assim: o cidadão deve poder confiar em que aos seus actos ou às decisões públicas incidentes sobre os seus direitos, posições jurídicas e relações, praticados de acordo com as normas jurídicas vigentes, se ligam os efeitos jurídicos duradouros, previstos ou calculados com base nessas mesmas normas. Estes princípios apontam basicamente para: (1) a proibição de leis retroactivas; (2) a inalterabilidade do caso julgado, (3) a tendencial irrevogabilidade de actos administrativos constitutivos de direitos. (CANOTILHO, 1992, p. 377-378)
\end{abstract}

Haveria, com isso, certa exigência para que todos os atos que os órgãos do Estado praticassem guardassem correspondência com os anteriores. Para o presente estudo, tal relevância adstringe-se ao Poder Judiciário, pois, tal organismo, durante a atividade jurisdicional, pode declarar a inconstitucionalidade de alguma lei, ou mesmo alterar o entendimento que lhe fora fixado (pelo próprio tribunal ou outro que lhe preceda), causando transtornos aos padrões anteriormente referidos.

Tais princípios proteção da confiança e segurança jurídica ainda atuam como notável instrumento para a verificação da legitimidade constitucional de leis ou outros atos normativos que possam ter como consequência a aplicação retroativa dos seus efeitos, causando ofensa a direitos fundamentais. Com isso, tais princípios se tornam mais uma maneira de se garantir a eficácia de tal cláusula pétrea.

Após breve exposição acerca de tais princípios, convém agora colocar tal problema dentro do assunto principal deste trabalho: a modulação de efeitos em matéria tributária.

\footnotetext{
${ }^{43}$ Art. $5^{\circ}$ Todos são iguais perante a lei, sem distinção de qualquer natureza, garantindo-se aos brasileiros e aos estrangeiros residentes no País a inviolabilidade do direito à vida, à liberdade, à igualdade, à segurança e à propriedade, nos termos seguintes: 
A relação se dá com o problema do abandono da tese que normalmente regula a declaração de inconstitucionalidade de uma lei e os efeitos de tal decisão, ou mesmo a alteração jurisprudencial, que altera um entendimento anterior, tido como válido.

Esse contexto, aliado ao fato de que o Judiciário pode ser encarado como a última trincheira de defesa dos interesses do cidadão, faz com que seja depositada uma confiança muito grande a tal poder, uma vez que ele que seria o responsável por retirar do mundo jurídico os exageros estatais.

Ao se dar aos Tribunais a função de intérprete final das normas, definindo, efetivamente, qual o sentido que deve ser dado a um comando legislativo, cria-se uma expectativa muito grande quando um Tribunal se manifesta acerca de uma matéria, criando-se a perspectiva de igual tratamento para todos os casos com relação a tal assunto.

A confiabilidade no Judiciário, portanto, apresenta duas formas: a externa (de mecanismo de defesa contra desmandos de outro poder); e a interna (que se baseia na expectativa de que os pronunciamentos judiciais não se alterem sem moderação).

Dessa forma, caso haja uma violação à confiança dos cidadãos por tal órgão, a transgressão é muito mais grave. Negando-se a proteger o cidadão, põe-se em xeque o próprio Estado de Direito. Ao alterar a interpretação, modifica-se, em último lugar, a própria norma, gerando grande insegurança acerca da atuação estatal. A necessidade de confiança que tiramos da atuação do Judiciário é, portanto, inegável. Por isso, a atividade jurisdicional deve ser pautada pela lógica e pela coerência.

Diante de tal exposição, fica clara a obrigação de se conciliar a necessidade de assegurar a segurança jurídica com a doutrina clássica de nulidade da lei inconstitucional, decorrência da supremacia da Constituição. Convém estabelecer quais os limites balizadores desse conflito. 


\section{3 - A modulação de efeitos em matéria tributária: requisitos e análise crítica da jurisprudência do STF}

\section{1 - O imperativo da aplicação do instituto da modulação de efeitos quando a decisão vai de encontro aos interesses do contribuinte e a sua impossibilidade quando a decisão é a favor do Fisco}

De toda a exposição feita neste trabalho, chega-se à conclusão de que a utilização do instituto da modulação de efeitos, fundada no argumento consequencialista, só pode existir quando há o intuito de proteger o cidadão, seja quando o Tribunal declara a inconstitucionalidade de uma norma, seja quando altera o entendimento anteriormente fixado.

A demonstração do conceito de Estado de Direito desenvolvido por Canotilho bem como todos os seus elementos estruturantes: juridicidade, constitucionalidade, sistema de direitos fundamentais, separação de poderes e princípios da legalidade, da segurança jurídica e da confiança dos cidadãos, bem como os seus desdobramentos teve o objetivo claro de demonstrar que nesse sistema o interesse principal é o de resguardar um espaço mínimo de autonomia, no qual o Poder Público não pode interferir.

Dessa forma, não se coaduna com a noção de Estado de Direito a decisão que, sob o argumento de que os seus efeitos poderiam causar graves consequências ao erário ou ao bom funcionamento da Administração, acaba mitigando os direitos fundamentais sem prévia autorização no ordenamento jurídico. A formulação teórica do conceito desde as suas origens liberais rechaça tal hipótese.

Isso se torna ainda mais perceptível quando estamos debatendo casos em que se discutem tributos, vez que, pela natureza ex lege da obrigação tributária, o poder tributante obteria nos princípios da legalidade e da irretroatividade os contornos em que poderia atuar. (ANDRADE, 2011).

A respeito, tem-se a lição de Alexandre Macedo Tavares:

\footnotetext{
Em suma: se o princípio republicano pressupõe uma obrigação tributária autoconsentida, a lealdade passa a arvorar-se como uma condicionante do lídimo exercício do poder de tributar, pois, se é o povo que tributara a si mesmo, não há como aceitar-se ou convalidar-se ainda que temporalmente, mediante o temido e acrítico expediente da atribuição da eficácia prospectiva às decisões de inconstitucionalidade em matéria tributária qualquer ato representativo de deslealdade, ante a despropositada e inimaginável concepção que alguém seja desleal consigo mesmo. (TAVARES, 2008, p. 14-15.)
}

Assim, a partir do momento em que uma exação é declarada inconstitucional, a tentativa de mantê-la no ordenamento é contrária aos princípios republicano e democrático 
ambos inseridos na nossa Constituição. Com isso, não deve ser aplicada a modulação de efeitos em prejuízo dos contribuintes (ANDRADE, 2011).

Em sentido semelhante, mas delimitando o tema com relação à alteração jurisprudencial, temos a lição de Misabel Derzi:

O princípio da proteção da confiança e da irretroatividade são princípios e direitos
fundamentais individuais, que somente o privado pode reivindicar, em contraposição
à Administração Pública, ao Poder Legislativo e Poder Judiciário, quando os
Poderes do Estado criam o fato gerador da confiança. Essa a razão de sua invocação
apenas em presença da modificação jurisprudencial em detrimento do contribuinte.
(DERZI, 2009, p. 604)

A autora assevera ainda que tais princípios integrantes do conceito de Estado de Direito consistiriam verdadeira limitação ao poder de tributar, apresentando-se como uma demonstração da segurança jurídica. Ademais, é perceptível a dependência do cidadão em relação ao Estado, mas não aconteceria o inverso, uma vez que o ente estatal disporia de mais meios para se prevenir de uma decepção (DERZI, 2009).

Ao se apresentarem como limitações ao poder de tributar, não poderia o julgador, dentro de tal decisão, determinar que o diploma permanecesse válido mesmo após a declaração de sua nulidade. O princípio do nullum tributum sine lege em conjunto com o princípio da segurança jurídica exigiriam que toda transferência patrimonial do contribuinte ao ente estatal fosse pautada pela lei. Sem lei, não há exação. Isso, aliado ao dogma da nulidade da lei acolhido do sistema norte-americano, tal como acima abordado teria a consequência de tornar tal cobrança ilegal.

Do mesmo modo, a alteração da interpretação da norma, modificando um entendimento anterior, consistiria, na verdade, em um new principle of law, isto é, uma nova regra de direito que não pode ser aplicada em respeito ao princípio da irretroatividade das normas.

Além disso, tendo em vista a ultratecnicidade das normas tributárias, a base segura para a estruturação de um planejamento fiscal residiria na interpretação dada pela administração e pela jurisprudência. Com isso, uma alteração em tal entendimento deveria ser arem seus p. 246).

Uma solução diversa no sentido de se rejeitar a modulação, no entanto, deve ser tomada caso a declaração de inconstitucionalidade ou a modulação de efeitos seja a favor do 
Fisco, tendo em vista que não haveria quebra da previsibilidade. Esse último ponto é desenvolvido por Misabel Derzi, valendo-se das lições de Niklas Luhmann:

\begin{abstract}
Mas NIKLAS LUHMANN alerta para o fato de que onde não se coloca a possibilidade de variação incontrolada, não se põe a questão da confiança. Onde há supremacia sobre os eventos/acontecimentos, a confiança não é necessária. Essa constatação é importante nesta tese: a confiança e a proteção da confiança não se colocam do ponto de vista do Estado, como ente soberano. Isso porque, nas obrigações ex lege, o Estado tem supremacia sobre os eventos/acontecimentos que ele mesmo provoca, ou seja: as leis, as decisões administrativas e as decisões judiciais na modelação e cobrança dos tributos. (DERZI, 2009, p. 328)
\end{abstract}

Dessa maneira, caso se admita a possibilidade de modulação em favor do Estado, teríamos, como consequência, a vulnerabilidade do Estado de Direito, uma vez que, o ente político alcançaria uma posição jurídica melhor em face do cidadão da estabelecida em lei, o que seria impedido pela noção de Estado de Direito anteriormente desenvolvida. Convém lembrar: quando estamos no âmbito do Direito Público, direitos e deveres dos cidadãos decorrem diretamente da lei (DERZI, 2009).

Diante de tais premissas, conclui a autora:

\begin{abstract}
Se as modificações de jurisprudência ocorrem em detrimento das Fazendas Públicas, não se apresentam adequados, então, os princípios da irretroatividade, da proteção da confiança e da boa-fé objetiva, já que são limitações constitucionais do poder judicial de tributar. (...) Mas, evidentemente, a Constituição da República contém os instrumentos necessários, para proteger os fatos e atos pretéritos, se a alteração jurisprudencial surpreende o Ente estatal projetando-o em verdadeiro estado de necessidade administrativa. (DERZI, 2009, p. 607)
\end{abstract}

A partir de tais considerações, só se poderia admitir, portanto, a possibilidade de efeitos prospectivos das decisões apenas quando tal instituto tiver como objetivo a proteção dos interesses do contribuinte. Afinal, o Estado de Direito, no caso de modulação pró-Fisco ou de não-modulação pró-Contribuinte, caso estejam presentes as condições necessárias, estaria ameaçado ou consistiria em mera idealização.

Diante de tudo quanto exposto, a verdadeira missão dos efeitos prospectivos das decisões do Judiciário, ao menos quando em jogo Direitos Fundamentais, é a da proteção dos indivíduos. Nesse contexto, em se tratando de matéria tributária, encontra-se apenas legitimada a modulação em favor do Contribuinte, uma vez que apenas com essa é que se tem a concretização do Estado de Direito.

Analisar-se-á, no capítulo seguinte, se essa tem sido a inclinação do STF nos últimos julgados em matéria tributária. 


\section{2 - Modulação de efeitos em matéria tributária: casos da jurisprudência do STF}

\subsection{1 - Caso do IPI}

\section{i) Síntese da demanda}

Quando do julgamento do Recurso Extraordinário n. $353.657^{45}$, o Supremo Tribunal Federal enfrentou a questão do direito ao crédito de IPI decorrente da aquisição de matériaprima cuja entrada não é tributada ou sobre a qual incide uma alíquota igual a zero. Com relação a tal questão, por uma maioria apertada seis votos a cinco , deu-se provimento ao recurso aviado pela União, impossibilitando os contribuintes de se valerem de tal crédito.

Antes de analisar tal julgado, vale a pena lembrar que o STF havia apreciado a matéria nos ERE 94.177 e RE 212.484, que consistiriam na jurisprudência do Tribunal com relação ao tema (CASSONE, 2008). Com relação ao segundo, vale a pena lembrar que tendo em vista embargos de declaração opostos pela Fazenda tal recurso ainda não havia transitado em julgado.

Todavia, Vittorio Cassone (2008) lembra que, quando da apreciação da questão de ordem na Ação Cautelar n. 1.852, a 2a Turma do STF concedeu o direito ao crédito tãosomente quanto ao crédito presumido na aquisição de produtos isentos.

Após essa breve exposição acerca das peculiaridades do caso, convém agora abordar a questão da solicitação da modulação dos efeitos da decisão que negou direito a tal crédito de IPI.

Os argumentos dos contribuintes a favor da modulação de efeitos foram bem delimitados na lição de Fábio Martins de Andrade:

\footnotetext{
Os fundamentos jurídicos sustentados para a modulação de efeitos temporais na hipótese que examinou foram, em síntese, os seguintes: a observância do princípio caso, dos contribuintes) e da boa-fé nas relações entre eles e o Poder Público; e o respeito à regra da irretroatividade tributária. (ANDRADE, 2011, p. 387)
}

$\mathrm{O}$ argumento cinge-se ao fato de que uma decisão que modifica um entendimento anterior e que leva a consequente majoração do tributo só poderia valer para declarações futuras, uma vez que seria equivalente a uma norma nova que determina tal efeito.

Além disso, por haver decisões no sentido da tese dos contribuintes, o planejamento tributário de tais indivíduos foi no sentido de não preverem tal exação. Assim, uma modificação em tal previsão acabaria por afetar a fidúcia daqueles que confiaram nessa orientação jurisprudencial.

${ }^{45}$ O RE n. 370.682 foi julgado em conjunto. 
Por fim, o grande decurso de tempo entre a decisão que altera a jurisprudência e o acórdão que a firmou importaria em grandes prejuízos para aqueles que de boa-fé confiaram na orientação e assim conduziram as suas relações.

Com relação ao argumento fazendário, o seu principal ponto dizia respeito ao insistente inconformismo do Fisco com relação a tal jurisprudência que lhe era desfavorável. Essa circunstância é comprovada com a constatação de que o trânsito em julgado com relação aos acórdãos que asseveravam direito aos contribuintes do crédito não ter ocorrido. A interposição de recursos (agravo regimental e embargos de declaração) impediu que a decisão transitasse em julgado. Por isso, não haveria de se falar em mudança jurisprudencial.

Tais argumentos foram colocados ao crivo do Tribunal Pleno do STF, que decidiu, por maioria, vencido o Ministro Ricardo Lewandowski, não aplicar efeitos ex nunc a tal decisão.

Após fazer uma exposição acerca da possibilidade da aplicação do artigo 27 da Lei $n^{\circ}$ 9.868/99, o Ministro Ricardo Lewandowski fundamentou a sua intervenção no sentido da aplicação do dispositivo naquele caso, tendo em vista que, do ponto de vista dos contribuintes, haveria o pressuposto da segurança jurídica, o que justificaria a modulação de efeitos prevista na aludida norma.

Em seguida, o voto isolado do julgado em comento destacou a inexorável evolução que a jurisprudência e a legiferação estavam sujeitas. Todavia, lembrou que tal processo deve sempre ser pautado pela segurança. Nas palavras do julgador:

Não se pugna com isso, é evidente, a cristalização da jurisprudência ou a paralisia da atividade legislativa, pois as decisões judiciais e as leis não podem ficar alheias à evolução social e ao devir histórico. Não se pode olvidar, contudo, que cumpre, como sabiamente apontou a Ministra Cármen Lúcia, em magistral estudo que integra a coletânea de artigos em homenagem ao Ministro Sepúlveda Pertence, conferir segurança

Ademais, registrou o Ministro a sua preocupação com o grande número de ações rescisórias que vinham sendo ajuizadas para reverter o direito de crédito dado a alguns contribuintes. In verbis:

Para se ter uma idéia do grava que uma decisão ex tunc representaria para os jurisdicionados, registro que a União, antes mesmo da consolidação da nova maioria do Plenário, já vinha ingressando com ações rescisórias perante o Tribunal Federal da $4^{a}$ Região contra contribuintes que, com fundamento nos julgados anteriores do STF, obtiveram o direito de creditar-se do IPI nas operações isentas, não tributadas ou taxadas com alíquota zero. ${ }^{47}$

\footnotetext{
${ }^{46}$ RE n. 353.657

${ }^{47}$ RE n. 353.657
} 
Apenas para encerrar as considerações acerca do voto do Ministro Ricardo Lewandowski, convém consignar as partes do voto que sintetizam o seu pensamento no sentido da necessidade de modulação na demanda:

(...) convém emprestar-se efeitos prospectivos às decisões em tela, sob pena de impor-se pesados ônus aos contribuintes que se fiaram na tendência jurisprudencial indicadas nas decisões anteriores desta Corte sobre o tema, com todas as conseqüências negativas que isso acarretará nos planos econômicos e social.

(...)

Assim, Senhora Presidente, ante as peculiaridades do caso, e em homenagem não apenas ao princípio da segurança jurídica, mas também aos postulados da lealdade, da boa-fé e da confiança legítima, sobre os quais se assenta o próprio Estado Democrático de Direito, proponho que se confira efeitos ex nunc as decisões proferidas nos RE 353.657 e 370.682 . $^{48}$

Abrindo a divergência, o Ministro Marco Aurélio deixou registrado que não poderia haver modulação porque isso corresponderia a uma mitigação da Constituição, como se isso fosse possível, além de se apresentar como um freio à passagem do tempo, o que é igualmente impensável. In verbis:

Ora, a fixação de um termo inicial de vigência do entendimento deste Plenário, além de implicar a mitigação da Constituição Federal, como se esta fosse flexível, como se esta não houvesse figurado até aqui, resultará em manifesta injustiça. A passagem do tempo é irrefreável, tendo conseqüências no mundo jurídico considerados os institutos da prescrição e da decadência.

Contribuintes que ingressaram em Juízo alcançarão, com o termo inicial de vigência que porventura venha a ser fixado, vantagem retroativa aos cinco anos anteriores ao ajuizamento da ação. Conseguirão o implemento do crédito, embora à margem da autorização normativa constitucional, como se esta não estivesse em vigor desde $1988 .^{49}$

No que tange ao argumento de ofensa à segurança jurídica, o Ministro o rejeitou sob o fundamento de que tal premissa não estava condizente com a realidade. Nas palavras do julgador:

No tocante à alegada segurança jurídica que proporcionou um sem-número de pareceres confesso que nunca presenciei tão grande movimentação, parte-se de premissa que não corresponde à realidade. $O$ tema sobre o creditamento, ao contrário de outros que, de qualquer forma, houve a reversão do quadro decisório, não chegou a ser pacificado no Tribunal. É certo que, em 18.12.2002, ao julgar os RE 350.446-1/PR, 353.668-1/PR, 353.277-6/RS e 358.493-6/SC, o Plenário proclamou esse direito, vencido, na oportunidade, o ministro Ilmar Galvão e impedido o ministro Maurício Corrêa. Não menos correto é que os acórdãos formalizados vieram a ser impugnados mediante declaratórios. Os interpostos nos três primeiros somente foram apreciados em fevereiro passado, quando proferi voto desprovendo-os. O trânsito em julgado não se confirmou em virtude da interposição

\footnotetext{
${ }^{48}$ RE n. 353.657

${ }^{49}$ RE n. 353.657
} 
de novos embargos. O último permanece concluso ao ministro Eros Grau que sucedeu o ministro Nelson Jobim na relatoria , para apreciação dos declaratórios. Então, não cabe dizer que o Supremo assentou, mediante acórdão coberto pela coisa julgada, o direito ao creditamento. A matéria estava pendente de decisão final pelo Plenário. $^{50}$

Por fim, registramos que o Ministro Marco Aurélio consignou que não se poderia cogitar de modulação de efeitos no caso em comento por não haver declaração de inconstitucionalidade.

Esse entendimento foi corroborado pelo voto da Ministra Cármen Lúcia, do qual extraímos o seguinte excerto:

Também penso que, neste caso, não houve declaração de inconstitucionalidade, houve mudança jurisprudencial, se é que houve, pois a Fazenda comprova que não teria havido essa revisão total e, neste caso específico, o contribuinte questionou algo que era presumido como inconstitucional, que era a atuação do Fisco; perdeu em Primeira Instância, portanto não se pode falar realmente em afronta ao princípio da segurança jurídica. ${ }^{51}$

Em seguida, o Ministro Eros Grau reforça os argumentos levantados pelo Ministro Marco Aurélio:

\begin{abstract}
Mas não é só. Aqui também não cabe cogitarmos de ameaça de qualquer ordem à segurança jurídica. Recebi em meu gabinete memorial da Procuradoria da Fazenda Nacional no qual se demonstra que nenhuma decisão a respeito do tema, a alíquota zero, transitou em julgado. Como se falar, destarte, em mudança de jurisprudência que jamais foi fixada? Isso consubstanciaria um autêntico non sense. Não se pode alterar o que jamais foi fixado definitivamente por este Tribunal. $\mathrm{O}$ argumento de

transitado em julgado e nenhuma delas transitou em julgado! é quase ingênuo. $\mathrm{O}$ que detém força de verdade legal é a coisa julgada, cuja autoridade, quando reiterada, faz jurisprudência. Não houve, no caso, mudança de jurisprudência desta Corte, visto que ela essa jurisprudência não fora estabelecida. ${ }^{52}$
\end{abstract}

Entendeu ainda o Ministro que deveriam os agentes econômicos ter a cautela necessária, para que o aproveitamento de tal crédito só acontecesse com o possível pronunciamento definitivo com o trânsito em julgado. Além disso, enfatizou que não haveria nenhuma razão relacionada ao interesse social capaz de justificar a medida excepcional.

O Ministro Joaquim Barbosa, além de deixar registrado que não se poderia falar em modulação, por não ter havido a declaração de inconstitucionalidade, asseverou que o contribuinte que tivesse optado pelo registro dos créditos sem que tal direito estivesse sobre o

\footnotetext{
${ }^{50}$ RE n. 353.657

${ }^{51}$ RE n. 353.657

${ }^{52}$ RE n. 353.657
} 
abrigo do trânsito em julgado teria como expectativa razoável a tendência de aplicação do razões, dentre elas a mudança da orientação durante o transcurso das fases administrativas e 53 .

O Ministro Carlos Britto, confirmando os argumentos apontados pelos ministros que o antecederam, negou ultra-atividade à decisão, mas demonstrou certa simpatia à proposta:

Entretanto, Ministro Ricardo Lewandowski, reconhecendo que a tese de Vossa Excelência é muito boa, peço vênia para dizer que o caso não é muito bom. Seria uma tese excelente para um caso típico de jurisprudência consolidada, de cristalizada jurisprudência, naquele sentido de múltiplas decisões convergentes, uniformes, no mesmo sentido. A Doutora Luciana [Procuradora da Fazenda Nacional] evidenciou que há precedentes, porém todos eles desafinados ou adversados por recursos impeditivos do respectivo trânsito em julgado. ${ }^{54}$

Ainda reafirmando o quanto dito pelos antecessores, o Ministro Cezar Peluso inaugurou divergência na qual permaneceu isolado com relação ao marco temporal do efeito da decisão. In verbis:

Conforme se colhe do voto do Ministro Gilmar Mendes, o fundamento para a suposta mudança de entendimento foi a edição da Lei no 9.779/1999, que garantiu ao vendedor de produtos isentos, não tributados ou sujeitos à alíquota zero, o direito à manutenção e à transferência do crédito relativa às entradas tributadas.

Nesse sentido, o efeito da decisão, a meu ver, deveria alcançar apenas o início da vigência da lei, ou seja, 20/01/1999. ${ }^{55}$

O Ministro Gilmar Mendes, apesar de comungar das premissas teóricas em que o voto do Ministro Ricardo Lewandowski se baseia, acompanhou a divergência por entender que no caso dos autos não seria hipótese de modulação.

No mesmo sentido, o Ministro Sepúlveda Pertence acompanhou a maioria já consolidada, apenas consignando que

Após tais votos, a Ministra Presidente, Ellen Gracie, proferiu um voto sem muitas considerações, apenas afirmando que agradecia ao Ministro Ricardo Lewandowski pela questão suscitada, mas que concordava com a divergência ${ }^{57}$.

\footnotetext{
${ }^{53}$ RE n. 353.657

${ }^{54}$ RE n. 353.657

${ }^{55}$ RE n. 353.657

${ }^{56}$ RE n. 353.657

${ }^{57}$ RE n. 353.657
} 
Apenas para encerrar as considerações acerca do que consta dos acórdãos com relação ao tema, convém apenas deixar registrado o caráter consequencialista de cunho econômico que ambos adotam. Do trecho de um encontramos o seguinte:

\begin{abstract}
Recentemente, ao apreciar, a Primeira Turma, um agravo manifestado contra despacho que tivera por não ofensivo ao princípio da não-cumulatividade acórdão que reconheceu a contribuinte do IPI direito a crédito presumido relativo à matériaprima não sujeita ao referido imposto, no montante de $\mathbf{R} \mathbf{\$} \mathbf{2 5 0}$ milhões, foi sugerido a este Relator que pedisse vista do recurso e o mantivesse no aguardo de reapreciação, pelo Plenário, da questão do crédito presumido do IPI sobre matériaprima adquirida sob os regimes de isenção e alíquota zero, e, ainda, de nãotributação. ${ }^{58}$
\end{abstract}

Ressalte-se que os grifos estão no original. Além de tal alusão, o outro acórdão faz menção a artigo de autoria da jornalista Miriam Leitão. É de se conferir:

Daí artigo de Miriam Leitão, publicado em 11 de agosto corrente, no jornal $\mathrm{O}$ Globo, no qual deixou consignado:

Decidir contra o recurso pode causar uma sangria absurda nos cofres públicos. O fato mais grave é que, quanto mais supérfluo for o produto, maior será o benefício do produtor e o IPI tem como característica justamente onerar menos produtos considerados essenciais. Os não essenciais terão o maior ganho; é o caso do cigarro, por exemplo(...)

Em trecho anterior, a jornalista ressaltou:

O que torna mais preocupante esse assunto é que o gorverno apesar de que é claríssimo que ele tem razão já tinha sido derrotado no Supremo. ${ }^{59}$

Esse trecho demonstra que a questão discutida ou pelo menos a argumentação desenvolvida em parte do voto apresenta caráter fortemente consequencialista.

Após essa exposição de qual foi a linha desenvolvida pelo voto de cada Ministro, convém analisar criticamente tal acórdão.

\title{
ii) Comentários
}

Em primeiro lugar, deve-se ressaltar que a discussão, com relação à modulação dos efeitos, nesse caso, foi bastante intensa. Isso fica claro quando se detecta que cerca de $2 / 5$ da íntegra do acórdão ${ }^{60}$, de 260 páginas, tem como objeto tal questão.

Além disso, merece destaque o fato de que o argumento da segurança jurídica serviu como embasamento teórico tanto para a aplicação dos efeitos prospectivos já que haveria a alteração da jurisprudência anteriormente consolidada como para a tese que a rejeitava

\footnotetext{
${ }^{58}$ RE 370.682

${ }^{59}$ RE n. 353.657

${ }^{60}$ Tal informação diz respeito ao RE n. 353.657. Com relação ao RE n. 370.682, essa informação ganha ainda mais relevo porque o acórdão só tem 190 páginas, sendo que a discussão com relação à modulação é a mesma.
} 
ausência de expectativa legítima de tal entendimento, tendo em vista a ausência de trânsito em julgado das decisões. (ANDRADE, 2011.)

Diante de tal constatação nta, invariavelmente, significados diversos, de modo que a sua aplicação pode variar a partir do exame do julgador, como de fato ocorreu.

É imperioso perceber como aqui prevaleceu uma visão eminentemente formalista e positivista no julgamento da questão (ANDRADE, 2011). Pois, apesar de já se apresentar uma , tal como já fora aduzido (CASSANO, 2008), as reiteradas decisões foram combatidas por recursos que impediram o seu trânsito. Daí causa estranheza o fato de alguns $M$ caráter de coisa julgada.

Nesse ponto, devemos lembrar que o Informativo $\mathrm{N}^{\circ} 295$ traz a notícia de que o crédito em discussão havia sido concedido. Sabe-se que tal meio de ciência não representa coercitividade para manutenção de determinado julgado, mas não se deve ignorar que por compor uma forma de conhecimento da atividade do STF constitui um elemento de estabilização da confiança do jurisdicionado. Nenhum contribuinte espera que o julgado de uma semana seja alterado em curto período (mesmo porque não fica acompanhando o trânsito em julgado de eventual recurso protocolado), assim como não espera que embargos de declaração tenham o condão de reverter o entendimento do órgão julgador (mesmo que sejam opostos com efeitos infringentes, no caso dos embargos, a praxe forense tende a demonstrar que tal artifício não apresenta o resultado almejado).

Aliado a tal fato, temos o fato de que, com base no $\S 1^{\circ}$-A do artigo 557 do Código de Processo Civil ${ }^{61}$, o qual estabelece que o Relator pode decidir monocraticamente um recurso interposto, em nome e por delegação do Tribunal, vários Ministros proferiram decisões no sentido pleiteado pelos Contribuintes. Ora, nessas circunstâncias, se não se pode falar em irretroatividade, indubitavelmente podemos falar em proteção da confiança por meio da boafé objetiva (DERZI, 2009). Essa circunstância, aliás, seria totalmente idônea para se assegurar os efeitos prospectivos em favor do Contribuinte.

Um outro ponto que deve ser levantado é que tal prática acaba por estimular um efeito nefasto ao Judiciário brasileiro: o estímulo para que a parte vencida no mérito acabe

\footnotetext{
${ }^{61}$ Art. 557. O relator negará seguimento a recurso manifestamente inadmissível, improcedente, prejudicado ou em confronto com súmula ou com jurisprudência dominante do respectivo tribunal, do Supremo Tribunal Federal ou de Tribunal Superior.

$\S 1^{\circ}$-A Se a decisão recorrida estiver em manifesto confronto com súmula ou com jurisprudência dominante do Supremo Tribunal Federal, ou de Tribunal Superior, o relator poderá dar provimento ao recurso.
} 
manejando todos os recursos possíveis e imagináveis, até que sobrevenha o pronunciamento definitivo com o trânsito em julgado (ANDRADE, 2011).

Nesse ponto, surgem algumas questões: quantos desses recursos foram meramente protelatórios? Quantos dos recursos apresentariam fundamentos suficientes para alterar o resultado $?^{62}$

Vale a pena rememorar que a reversão do precedente não ocorreu nesses casos. Deu-se em outro, levado para julgamento a partir da profunda mudança na composição do Pleno (ANDRADE, 2011). Ora, diante de tal fato, pode-se vislumbrar que a mensagem passada pela Corte é a de que se deve recorrer ao máximo; quem sabe o entendimento, com a modificação da composição dos Ministros, seja alterado. Um dos efeitos disso é o aumento do número de recursos que enchem as prateleiras dos tribunais. Tal fato tão combatido acaba sendo estimulado por tal conduta.

Ademais, tal prática, estimulada pela mudança dos Ministros integrantes da Corte, faz com que se dê maior relevância aos pensamentos individuais de cada Ministro, enfraquecendo a supremacia do Colegiado, que deveria zelar pela coerência (ANDRADE, 2011).

Não se deve olvidar que a medida também acaba por aumentar a beligerância entre Fisco e Contribuintes, que, estimulados a praticar atos de inconformismo com as decisões judiciais, farão com que, de modo exagerado, interponham recursos para evitar o trânsito em julgado.

Deve-se realçar que, ainda que grande parte dos Ministros tenha se manifestado no sentido da inaplicabilidade da modulação de efeitos pela ausência do seu pressuposto previsto no artigo 27 da Lei 9.868/99 a declaração de inconstitucionalidade , entendemos, na linha rte Suprema deixou patente a possibilidade de modular os efeitos das decisões modificativas de jurisprudência anterior, no RE 370.682(DERZI, 2009, p. 520).

Por fim, insta destacar outro argumento utilizado para a não aplicação dos efeitos prospectivos: a diferenciação do tratamento. Os Ministros apresentaram sensibilidade à possibilidade de se privilegiar aqueles Contribuintes que ingressaram em juízo e que se privilegiariam de tal pedido de crédito em relação aos outros Contribuintes que não ingressaram e simplesmente recolheram corretamente a exação. Tal argumento será importante no cotejo com o próximo caso a ser analisado.

\footnotetext{
${ }^{62}$ Outro tema que não deveria passar despercebido é o de que tal afirmação dos Ministros presume que tais recursos são presumivelmente conhecíveis. Se não o fossem, teríamos o trânsito e, consequ
} 


\subsubsection{Caso da decadência e prescrição das contribuições sociais}

\section{i) Síntese da demanda}

O STF, no julgamento do Recurso Extraordinário n. $560.626^{63}$, resolveu a questão da constitucionalidade dos artigos 45 , caput, e 46 da Lei 8.212/91 ${ }^{64}$ e o parágrafo único do artigo $5^{\circ}$ do Decreto-Lei $1.569 / 77^{65}$. No que tange ao parágrafo único, o dispositivo era questionado em relação ao artigo $19, \S 1^{\circ}$, da Constituição de $1967^{66}$, com a redação dada pela Emenda Constitucional $\mathrm{n}^{\circ}$ 01, de 1969. Com relação às normas da Lei 8.212/91, a inconstitucionalidade era sustentada pela contrariedade ao artigo 146, III, b, da Constituição Federal de $1988^{67}$.

A discussão desse caso consistia em saber se tais diplomas versariam sobre norma geral de Direito Tributário, pois, se assim se entendesse, deveriam ser declarados inconstitucionais, uma vez que na Constituição anterior e na atual tais preceitos só podem ser regulados por lei complementar.

A Corte acabou entendendo que nessa hipótese há a exigência de lei complementar para a disciplina dos institutos da decadência e da prescrição tributárias, inclusive quanto à definição de prazos e de hipóteses de suspensão da fluência correspondente.

Após a declaração da inconstitucionalidade de tais dispositivos, o STF enfrentou a questão da modulação de efeitos. Nesse ponto, chegou-se à conclusão de que os efeitos decorrentes da nulidade das normas só deveriam valer de forma ex nunc, atingindo apenas aquelas ações de repetição de indébito ajuizadas antes do julgamento do recurso extraordinário. Ou seja, aqueles Contribuintes que não tivessem pleiteado a restituição dos valores indevidamente pagos não poderiam ter a devolução da quantia paga se não tivessem reivindicado o seu direito seja em âmbito administrativo ou judicial.

No acórdão que resolveu tal questão, o fundamento que embasa tal decisão limita-se, basicamente,

ue se pode ter na

\footnotetext{
${ }^{63}$ Tal recurso foi julgado em conjunto com o RE 556.664 e o RE 559.882. O julgamento de tais recursos serviu como fundamento para a

1.569/1977 e os artigos 45 e 46 da Lei no 8.212/1991, que tratam de prescrição e decadência de crédito

${ }^{64}$ Art. 45. O direito da Seguridade Social apurar e constituir seus créditos extingue-se após 10 (dez) anos contados:

(...)

Art. 46. O direito de cobrar os créditos da Seguridade Social, constituídos na forma do artigo anterior, prescreve em 10 (dez) anos.

${ }^{65}$ Art $5^{\circ}$ Sem prejuízo da incidência da atualização monetária e dos juros de mora, bem como da exigência da prova de quitação para com a Fazenda Nacional, o Ministro da Fazenda poderá determinar a não inscrição como Dívida Ativa da União ou a sustação da cobrança judicial dos débitos de comprovada inexequibilidade e de reduzido valor.

Parágrafo único - A aplicação do disposto neste artigo suspende a prescrição dos créditos a que se refere.

${ }^{66} \S 1^{\circ}$ - Lei complementar estabelecerá normas gerais de direito tributário, disporá sobre os conflitos de competência tributária entre a União, os Estados, o Distrito Federal e os Municípios, e regulará as limitações constitucionais do poder tributário.

${ }^{67}$ Art. 146. Cabe à lei complementar:

(...)

III - estabelecer normas gerais em matéria de legislação tributária, especialmente sobre:

(...)

b) obrigação, lançamento, crédito, prescrição e decadência tributários;
} 
hipótese ${ }^{68}$. Com isso, percebemos a insuficiência de argumentos jurídicos capazes de autorizar os efeitos prospectivos. Os argumentos, na íntegra, estão expostos no voto do Ministro Gilmar Mendes:

Estou acolhendo parcialmente o pedido de modulação de efeitos, tendo em vista a repercussão e a insegurança jurídica que se pode ter na hipótese; mas estou tentando delimitar esse quadro de modo a afastar a possibilidade de repetição de indébito de valores recolhidos nestas condições, com exceção das ações propostas antes da conclusão do julgamento.

Nesse sentido, eu diria que o Fisco está impedido, fora dos prazos de decadência e prescrição previstos no CTN, de exigir as contribuições da seguridade social. No entanto, os valores já recolhidos nestas condições, seja administrativamente, seja por execução fiscal, não devem ser devolvidos ao contribuinte, salvo se ajuizada a ação antes da conclusão deste julgamento.

Em outras palavras, são legítimos os recolhimentos efetuados nos prazos previstos nos arts. 45 e 46 e não impugnados antes da conclusão deste julgamento.

Portanto, reitero o voto pelo desprovimento do recurso extraordinário, declarando a inconstitucionalidade do parágrafo único do Decreto-Lei ${ }^{\circ} 1.569$ e dos arts. 45 e 46 da Lei $n^{\circ} 8.212$, porém, com a modulação dos efeitos, ex nunc, apenas e em relação às eventuais repetições de indébito ajuizadas após a presente data, a data do julgamento. ${ }^{69}$

Apresentando voto divergente com relação ao tema, o Ministro Marco Aurélio combateu os argumentos da imprevisibilidade da decisão:

\begin{abstract}
A matéria versada não é nova e o primeiro pronunciamento do Tribunal quanto à necessidade de lei complementar recordo que a Lei 8212/91 é de 24 de julho de 1991 ocorreu em 1992. Este plenário já estava inclusive compondo-o , sem voto discrepante, assentou, na dicção do relator, ministro Carlos Velloso, a indispensável observância do instrumento lei complementar para alcançar-se a disciplina da prescrição e da decadência. Assim, repito e aqui não se pode cogitar de surpresa para quem quer que seja, muito menos para o Estado (... $)^{70}$
\end{abstract}

A partir de tais argumentos, buscou o voto divergente demonstrar que a situação não apresentava uma quebra na expectativa jurisdicional, pois o posicionamento se não pacífico , já se encaminhava no sentido de declarar a inconstitucionalidade dos aludidos dispositivos.

De todo modo, não foi esse o entendimento que prevaleceu no STF. A Corte estabeleceu que deveriam ser dados efeitos prospectivos para tal decisão, nos moldes do Relator, Ministro Gilmar Mendes.

Convém agora examinar tal julgado.

\footnotetext{
${ }^{68}$ RE n. 560.626

${ }^{69}$ RE n. 560.626.

${ }^{70}$ RE 560.626.
} 


\section{ii) Comentários}

Se a decisão anteriormente estudada era digna de críticas, essa se apresenta ainda mais censurável.

Esse julgado foi o primeiro em que o STF concedeu efeitos prospectivos a uma decisão em matéria tributária, determinando que fossem dados efeitos ex nunc nas condições especificadas.

No entanto, nessa ocasião, ao contrário do primeiro julgado, temos uma fundamentação parca e carente de fundamentos jurídicos sólidos capazes de justificar tal razão de decidir.

Por ser representado por homens, falíveis por natureza, espera-se que todos os seus atos sejam justificados, postos sob o crivo da razão, para conferir a validade necessária exigida pelo ordenamento jurídico.

A Constituição Federal determina em seu artigo 93, $\mathrm{IX}^{71}$, que todos os órgãos do Judiciário deverão fundamentar as suas decisões. Quando o órgão em questão é o responsável por ditar grande parte dos entendimentos que vão prevalecer no direito pátrio, a conclusão é de que tal dever torna-se imprescindível. Como o dogma que rege a declaração de inconstitucionalidade no direito pátrio tem efeitos ex tunc, estes que deveriam ditar a regra do caso. Ainda que se admita a possibilidade de aplicação de efeitos prospectivos, tal determinação deve ser estabelecida com o sopesamento dos méritos e deméritos, tal como anteriormente estudado.

Além disso, tal como pode ser observado do trecho do voto do Ministro Marco Aurélio anteriormente transcrito, a decisão do STF, com relação à questão de mérito, era mais do que esperada, tendo em vista os inúmeros posicionamentos convergentes que indicavam a necessidade de se ter uma lei complementar regulando a matéria em questão, ou seja, no sentido de se declarar inconstitucionais os artigos 45 e 46 da Lei $n^{\circ}$ 8.212/91.

Com relação à possibilidade de se modular os efeitos da decisão, deve-se ressaltar que, no caso em debate, a declaração de inconstitucionalidade, um dos requisitos necessários para a modulação de efeitos, tal como exigido por alguns Ministros no julgamento do crédito de IPI, estaria presente.

Fábio Martins de Andrade (2011), no entanto, aduz que não seria esta a hipótese, uma vez que o mero repisar da jurisprudência pacificada há décadas pela Corte e reconhecida em

\footnotetext{
${ }^{71}$ Art. 93. Lei complementar, de iniciativa do Supremo Tribunal Federal, disporá sobre o Estatuto da Magistratura, observados os seguintes princípios:

IX- todos os julgamentos do Poder Judiciário serão públicos, e fundamentadas todas as decisões, sob pena de nulidade, podendo a lei limitar a presença, em determinados atos, às próprias partes e a seus advogados, ou somente a estes, em casos nos quais a preservação do direito à intimidade do interessado no sigilo não prejudique o interesse público à informação.
} 
todas as demais esferas de julgamento do País não teria o condão de se encaixar nos

Mesmo que não houvesse o reconhecimento pelas demais instâncias do Judiciário, ainda sim entendemos que não seria o caso de modulação, uma vez que a jurisprudência do STF (a qual deveria regular a hipótese, em verdade) já estava consolidada. Não haveria, portanto, a ofensa à segurança jurídica.

$\mathrm{Na}$ verdade, esse mandamento foi abalado com a decisão tomada pelo plenário, na medida em que ela é violadora de direitos fundamentais do Contribuinte. Nesse sentido, o Supremo Tribunal Federal, disfarçando o real motivo da decisão conveniência econômica para o Estado acabou solapando os interesses subjetivos. A Corte acabou se impressionando com o argumento do eventual déficit de bilhões de reais.

Essa decisão acaba por ratificar uma forma de enriquecimento ilícito por parte do Estado que, ciente de que a lei editada apresentava fortes indícios de inconstitucionalidade o que pode ser observado pelas severas críticas apontadas ao dispositivo e a outros semelhantes, desde a sua promulgação , acaba por mantê-lo em vigor, beneficiando-se daqueles contribuintes que não ingressaram em juízo para questionar o tributo ou que, mesmo que com direito de questionar a exação, foram tolhidos de tal garantia pela decisão do STF. Acerca do tema, temos os ensinamentos de Misabel Derzi:

O Estado é protegido, de forma difusa, embora tivesse ele mesmo provocado a
cobrança, com base em lei inconstitucional e os ônus dessa proteção serão
suportados por um grupo de contribuintes, os conformados. Ora, a lei
inconstitucional é de autoria do Estado (Poder Legislativo), mas também a
iniciativa, ou seja, o projeto foi elaborado dentro do próprio Poder Executivo (que
incorporou antigo Decreto-Lei). A aplicação da lei foi seguida religiosamente,
quando as contestações aumentavam e a Dogmática, de forma unânime, apontava a
irregularidade. Afinal, as declarações de constitucionalidade foram inventadas
exatamente para isso. Além do mais, a repetição do indébito está limitada ao prazo
prescricional de cinco anos, quando os valores recebidos nos últimos vinte anos já
não poderão ser integralmente devolvidos. As vantagens da Fazenda Pública ainda
seriam notáveis, mesmo se os efeitos da decisão tivessem seguido a regra de se unir
a declaração de inconstitucionalidade à de nulidade. (DERZI, 2009, p.527)

Insta destacar que a Professora Misabel, no trecho acima, destaca um ponto de que

ajuizamento da Ação Declaratória de Inconstitucionalidade. Todavia, mesmo sabendo da forte resistência da incidência da exação, continuou cobrando a quantia indevida.

Além disso, merece destaque também a crítica que é feita a tal decisão por teoricamente violar o princípio da isonomia, que está previsto no caput do artigo $5^{\circ}$, de uma 
forma geral, e no inciso II do artigo 150, de forma específica aos contribuintes ${ }^{72}$. Nesse ponto, percebemos que o Tribunal aplicou critérios diferentes em situações que se assemelhavam: enquanto no caso do IPI tal questão foi ventilada, servindo inclusive como fundamento para se negar a modulação em favor dos Contribuintes, aqui sequer foi cogitada.

E o pior: sonegadores e inadimplentes, que não seguiram o quanto previsto na legislação, foram beneficiados por tal declaração de inconstitucionalidade. Já aqueles contribuintes que pagaram regularmente o tributo, mas que não ingressaram com o pedido de restituição, tiveram de sofrer com tal pagamento indevido.

derrocada dos pilares do Estado Democrático de Direito, o extermínio da ética estatal, a negação do que há de mais essencial às noções de igualdade e p.15).

Diante de tais circunstâncias, ao que parece, os efeitos pro futuro dessa decisão acabam por infringir os princípios da isonomia e da segurança jurídica, sob a influência do argumento consequencialista de natureza econômica. Tal sucumbência traz algumas tendências preocupantes.

Em primeiro lugar, reforça a mensagem anteriormente aduzida para o caso do IPI: é interessante continuar recorrendo. Nesse sentido, temos a lição de Fábio Martins de Andrade:

\begin{abstract}
Aplicando-se aos órgãos públicos em geral e fazendários em particular a mensagem é a seguinte: recorra sempre de tudo e, quando pensar que a questão está definida pela Suprema Corte não se esqueça de recorrer e, depois que obtiver eventual provimento jurisdicional contrário, daí recorra dele também. Com isso, o , ao invés de ser paulatinamente desestimulado pela adoção de medias neste sentido, torna-se mais forte do que nunca. (ANDRADE, 2011, p. 432)
\end{abstract}

Mesmo com o pronunciamento de julgados que muitos se assemelhavam ao caso e a jurisprudência firme das instâncias inferiores em asseverar a inconstitucionalidade do dispositivo , a Fazenda Nacional conseguiu que uma tese jurídica que lhe era totalmente desfavorável tivesse um resultado bastante favorável aos seus interesses.

Além disso, deve-se advertir para que fato de que o Supremo Tribunal Federal apresentou-se extremamente suscetível ao argumento consequencialista, mesmo sem qualquer embasamento jurídico ou uma simplória argumentação que o motivasse. A argumentação do

\footnotetext{
${ }^{72}$ Art. $5^{\circ}$ Todos são iguais perante a lei, sem distinção de qualquer natureza, garantindo-se aos brasileiros e aos estrangeiros residentes no País a inviolabilidade do direito à vida, à liberdade, à igualdade, à segurança e à propriedade, nos termos seguintes:

Art. 150. Sem prejuízo de outras garantias asseguradas ao contribuinte, é vedado à União, aos Estados, ao Distrito Federal e aos Municípios: (...)

II - instituir tratamento desigual entre contribuintes que se encontrem em situação equivalente, proibida qualquer distinção em razão de ocupação profissional ou função por eles exercida, independentemente da denominação jurídica dos rendimentos, títulos ou direitos;
} 
rombo aos cofres públicos passa a ter um valor maior que qualquer argumento jurídico, solapando-se a proteção dos direitos fundamentais, pedra angular do nosso ordenamento jurídico.

Isso se mostra ainda mais preocupante quando temos em jogo matéria tributária, porque a tendência nessa seara é justamente essa: de um lado, os direitos fundamentais, do outro, enormes quantias capazes de causar verdadeiros rombos no erário, ou em contribuintes.

Esse argumento ad terrorem, nos dizeres de Fábio Martins de Andrade (2011), causa ainda outro inconveniente, que é a instigação para que o Poder Público ainda tenha outra instância: a modulação de efeitos no STF. O perigo de tal orientação é aduzido por Fábio Martins de Andrade:

\footnotetext{
inaugurado um período intencional e parcialmente vocacionado em sentido favorável ao Fisco nas disputas tributárias, seja pelo encampamento acrítico do argumento econômico ad terrorem, seja pela aceitação do lobby engendrado pelos Ministros de Estado da Fazenda e outras autoridades da República junto aos Ministros da Corte, seja ainda pelo sentimento de simpatia pessoal ou convicção política de alguns deles para com o governo. (ANDRADE, 2011, p. 437)
}

Tal afirmação tem arrimo no fato de que situações semelhantes tiveram diferentes soluções. O argumento econômico ventilado pelos Contribuintes foi rechaçado com o argumento de que os empresários deveriam planejar as suas atividades. $\mathrm{O}$ argumento econômico sustentado pelo Fisco foi acolhido, mesmo com a ausência de argumento jurídico, sob a preocupação de que causaria danos indesejáveis à previdência. É o mesmo peso com diferentes medidas.

\subsection{3 - O caso da isenção da COFINS às sociedades civis de prestação de serviços com profissão regulamentada}

\section{i) Síntese de demanda}

Pouco tempo depois da decisão supracomentada, o Supremo Tribunal Federal, nos autos do Recurso Extraordinário n. 377.457, foi novamente chamado a deliberar acerca da necessidade de modulação de efeitos das suas decisões.

Agora, discutia-se a constitucionalidade do artigo 56 da Lei $\mathrm{n}^{\circ} 9.430$, que revogava a isenção da COFINS concedida às sociedades civis de prestação de serviço de profissão regulamentada pela Lei Complementar $n^{\circ}$ 70/1991. 
Antes de aduzir em que termos o STF decidiu a matéria, convém destacar duas questões. O primeiro ponto diz respeito a alguns julgados ${ }^{73}$ da Corte que já se manifestavam no sentido de que a matéria em discussão não era de sua competência. Sob o fundamento de que a ofensa ao texto constitucional seria apenas reflexa ou indireta, rejeitava-se o exame do tema.

O segundo ponto diz respeito ao fato de que o Superior Tribunal de Justiça, dentro dos limites da sua competência constitucional de protetor da legislação federal infraconstitucional, havia pacificado o seu entendimento sobre a matéria, nos termos da Súmula ${ }^{\circ} 276^{74}$ daquele Tribunal, juízo esse que ia ao encontro dos interesses do Contribuinte.

Dito isso, convém agora analisar a decisão do STF. A Corte, modificando o entendimento anteriormente fixado de impossibilidade de análise extraordinária, resolveu apreciar a questão do conflito entre lei ordinária que extinguira a isenção e lei complementar que a garantia. Com relação ao mérito, a Corte decidiu que a Lei Complementar $n^{\circ} 70 / 91$, no que diz respeito à parte que institui a Contribuição Social, seria formalmente complementar, mas a matéria disciplinada seria de competência de lei ordinária. Com tais fundamentos, concluiu-se pela revogação do instituto pró-Contribuinte.

Em relação à modulação de efeitos, mesmo com toda argumentação no sentido de demonstrar a necessidade de se aplicar efeitos prospectivos a tal decisão tendo em vista os dois pontos anteriormente narrados, que notavelmente abalariam a segurança jurídica dos Contribuintes , o STF, após um empate, entendeu por bem rejeitar o pedido de modulação.

Quanto aos argumentos que embasaram tal decisão, percebemos que o STF, dessa vez, apresentou uma maior fundamentação em relação ao observado no caso anteriormente descrito. Nesse sentido, destacamos, no que tange à impossibilidade de modulação de efeitos da matéria discutida nos autos do Recurso Extraordinário n. 377.457, que o Ministro Gilmar Mendes, inicialmente, registra não ser cabível a sua aplicação por não se tratar de uma declaração de inconstitucionalidade de uma norma, mas sim de uma que a confirma. Além disso, o Ministro sufraga que o entendimento firmado estava caminhando para o que já afirmara a jurisprudência da Corte $^{75}$ e a doutrina.

\footnotetext{
${ }^{73}$ Nesse sentido temos o AI 509.534. Ainda podemos destacar trecho do voto do Ministro Ricardo Lewandowski no RE 377.457, que, ao $\mathrm{s} \quad$ onado com os distintos argumentos, (...), e agora com esse argumento levantado pelo eminente Ministro Celso de Mello, segundo o qual esta Suprema Corte sistematicamente considerava a matéria infraconstitucional, confirmando, portanto, entendimento daquela egrégia Corte, e entendimento a partir do julgamento do RE 419.629/DF e do RE 451.988-RS, dos quais foi relator o eminente Ministro Sepúlveda Pertence. Aí, Senhor Presidente,

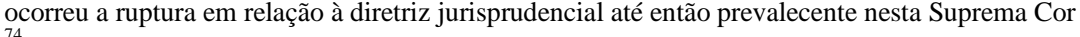


O julgador ainda enfatizava que, embora a situação estivesse pacificada nos outros Tribunais, não acontecera assim no Supremo, e que, se concedesse a modulação em tal hipótese, poderia o STF ter o mesmo posicionamento toda vez que alterasse decisão de outro Tribunal, circunstância temerosa na visão do então Presidente da Corte.

Acompanhando tal entendimento, a Ministra Cármen Lúcia asseverou ${ }^{76}$ que o STF, em sua atividade jurisdicional, há de fixar algumas balizas para a modulação, tal como a excepcionalidade da situação, a possibilidade de insegurança jurídica e a necessidade de sinalizar a atuação sobre determinada matéria que vier para frente. Tais padrões não eram verificados, de acordo com o seu entendimento, no caso.

Apenas para encerrar os argumentos contrários à modulação de efeitos no caso da isenção da COFINS às sociedades civis de prestação de serviços com profissão regulamentada, é válido transcrever parte do voto do Ministro Cezar Peluso:

\footnotetext{
Senhor Presidente, também peço vênia à divergência, para acompanhar Vossa Excelência por várias razões.

Primeiro, porque, realmente, como já sustentei no meu voto, com o devido respeito, não vi densidade jurídica que justificasse uma confiança dos contribuintes a respeito dessa tese.

Segundo, penso que não podemos, vamos dizer, baratear o uso analógico da modulação para os julgamentos no controle dos processos subjetivos, porque, se não, vamos transformá-la em regra: toda vez que alteramos a jurisprudência dos outros tribunais teremos, automaticamente, por via de conseqüência, de emprestar a mesma limitação.

Em terceiro lugar, no caso concreto, parece-me que, como se afirma a constitucionalidade, no fundo o Tribunal estaria concedendo moratória fiscal, se limitasse os efeitos. ${ }^{77}$
}

Com relação aos argumentos favoráveis à modulação de efeitos, destacamos os votos dos Ministros Menezes Direito e Celso de Mello. O primeiro, enfatizando o fato de o STJ ter firmado posicionamento em sentido diametralmente oposto ao fixado no Supremo, destacava a insegurança jurídica que isso poderia gerar. Ademais, lembrou que tal decisão poderia trazer consequências terríveis, uma vez que teria grande impacto em pequenos contribuintes. ${ }^{78}$

No mesmo sentido, e realçando a grave lesão aos cidadãos que tal mudança abrupta poderia causar, o Ministro Celso de Mello considerou que a modulação de efeitos era essencial para assegurar o princípio da segurança jurídica e da confiança do cidadão. Nas palavras do julgador:

\footnotetext{
${ }^{76}$ RE n. 377.457

${ }^{77}$ RE n. 377.457

${ }^{78}$ RE n. 377.457
} 
$\mathrm{Na}$ realidade, os postulados de segurança jurídica e da proteção da confiança, enquanto expressões do Estado Democrático de Direito, mostram-se impregnados de elevado conteúdo ético, social e jurídico, projetando-se sobre as relações jurídicas, inclusive as de direito público, sempre que se registre alteração substancial de diretrizes hermenêuticas, impondo-se à observância de qualquer dos Poderes do Estado e, desse modo, permitindo preservar situações já consolidadas no passado e anteriores aos marcos temporais definidos pelo Tribunal.

A ruptura do paradigma resultante de substancial revisão dos padrões judiciais, como sucede no caso, impõe, em respeito à exigência de segurança jurídica e ao princípio da confiança dos cidadãos, que se defina o momento a partir do qual terá aplicabilidade a nova diretriz hermenêutica. ${ }^{79}$

A fundamentação de tal voto foi tão eloquente que conseguiu convencer dois Ministros Ricardo Lewandowsi e Carlos Britto a retificarem seus votos. Apesar disso, o Tribunal acabou fixando que a decisão deveria valer imediatamente, atingindo situações pretéritas.

\section{ii) Comentários}

A primeira crítica que deve ser deixada a tal orientação é a de que se esperava uma maior reflexão entre a jurisprudência dos outros Tribunais representada pela súmula do STJ, responsável por uniformizar a jurisprudência de matérias infraconstitucionais e a decisão do STF. Não se deve enxergar com bons olhos o total desligamento entre tais órgãos de cúpula do Judiciário.

Essa situação tem ainda um agravante: o STF vinha se manifestando no sentido de que a matéria era infraconstitucional, ou seja, por lhe faltar ofensa à Constituição, não poderia ter seu mérito julgado pela Suprema Corte. Com isso, o entendimento que prevalecia era o fixado no STJ, nos moldes da súmula editada.

Essa questão é comentada por Fábio Martins de Andrade:

É precisamente neste momento que sobressai a violação aos princípios da proteção da confiança e da boa-fé, como sustentáculos do pilar da segurança jurídica, que, por sua vez, é inerente ao Estado Democrático de Direito. (...) Afinal, a relação a ser estabilizada e pacificada não é entre contribuintes de um lado e o Supremo Tribunal Federal, de outro. (ANDRADE, 2011, p. 462-463.)

Esses argumentos segurança jurídica, proteção da confiança e da boa-fé foram demonstrados pelo Ministro Celso de Mello, que, asseverando como as súmulas exercem um papel fundamental na segurança das relações entre os jurisdicionados, mostrou como o enunciado sumular não poderia ser ignorado ${ }^{80}$.

\footnotetext{
${ }^{79}$ RE n. 377.457

${ }^{80}$ RE n. 377.457
} 
Mesmo com tal robusto argumento, a Ministra Cármen Lúcia consignou que os efeitos prospectivos só são possíveis em situações excepcionais e que envolvam a possibilidade de insegurança jurídica. Além disso, asseverou que o instituto da

81. Ora, não seria esse o caso de alteração substancial da jurisprudência? Não seria essa uma boa oportunidade para começar tal tarefa? Evidentemente, essa parte da crítica pode ser estendida aos demais Ministros.

Insta ressaltar ainda dar destaque a trecho do voto do Ministro Cezar Peluso, no qual

moratória fisca

${ }^{82}$. Esse argumento é combatido por Fábio Martins de

Andrade:

\begin{abstract}
Parece-nos que o reconhecimento do que o Ministro Cezar Peluso chamou de há tanto tempo vem enriquecendo o Estado. Ele entende que a concessão de

questões em suas próximas manifestações, sobretudo, quando reconhecida a constitucionalidade de determinada exação tributária. (ANDRADE, 2011, p. 467.)
\end{abstract}

Do outro lado da moeda teríamos o caso semelhante ao exposto prazo quinquenal para prescrição e decadência de créditos tributários em que ocorreu o enriquecimento ilícito pelo Estado de quantias declaradas inconstitucionais e que ingressaram definitivamente nos cofres públicos em virtude, e.g., de prescrição ou de decadência.

Do mesmo modo, é importante demonstrar que um ponto que foi levantado mais uma vez tal como no caso do IPI, anteriormente exposto foi o da preocupação com o uso desenfreado da modulação dos efeitos. Mesmo que tal apreensão seja legítima, convém indagar o motivo da sua não cogitação quando do julgamento da prescrição e da decadência de créditos tributários.

É válido ainda trazer a ideia de Fábio Martins de Andrade (2011), para quem a oposição de embargos de declaração neste caso tem o condão de permitir ao Tribunal rever a posição de negativa de efeitos pro futuro da decisão.

Diante de tal possibilidade, Andrade propõe que, tendo em vista a alteração da jurisprudência dominante, e em respeito aos princípios da proteção da confiança, da boa-fé e da irretroatividade, seja dado efeitos ex nunc a tal decisão.

\footnotetext{
${ }^{81}$ RE n. 377.457

${ }^{82}$ RE n. 377.457
} 
A solução dada pelo autor é abaixo exposta.

A corte poderia ir mais longe, respeitando a anterioridade nonagesimal prevista no $\S 6^{\circ}$ do art. 195 da Constituição da República, que se aplica para a instituição ou majoração de contribuições sociais. Com efeito, têm-se valiosas defesas no sentido de que o princípio da irretroatividade tributária serve de sustentáculo do princípio da segurança jurídica, a qual é inerente ao Estado Democrático de Direito. (ANDRADE, 2011, p. 469)

Com a aplicação pro futuro de tal decisão, estar-se-ia aplicando a decisão mais justa para o caso em comento (ANDRADE, 2011).

\subsection{4 - O caso da Contribuição ao FUNRURAL}

\section{i) Síntese da demanda}

Nos autos do RE n. 363.852 o Supremo Tribunal Federal discutiu a validade da incidência da Contribuição Social sobre comercialização da produção rural, exigida de empregadores rurais pessoas físicas ou dos adquirentes dos seus produtos, nos moldes do artigo $1^{\circ}$ da Lei 8.540, que deu nova redação aos artigos 12, inciso V e VIII, 25, incisos I e II e 30, inciso IV, todos da Lei ${ }^{\circ} 8.212 / 91$.

No caso, a Corte asseverou que tal exação era inconstitucional, sob o fundamento, entre outros, de que tal norma só poderia ser instituída por Lei Complementar. Tal fato traz como consequência lógica o reconhecimento de que a arrecadação pecuniária foi indevida, devendo, portanto, ser restituída.

Diante de tal conclusão, a Fazenda Nacional formulou pedido de modulação dos efeitos da decisão, e o Tribunal passou a analisar tal possibilidade.

Entre os argumentos contrários à aplicação de efeitos prospectivos a decisão os quais representaram a grande maioria , o Relator, Ministro Marco Aurélio, destacou a impossibilidade de se mitigar a eficácia da Carta Magna, pois isso implicaria uma inversão de valores, fazendo com que uma lei inconstitucional tenha validade alargada no tempo. Além disso, frisou ser a primeira vez que havia um pronunciamento do Tribunal acerca do tema, ou seja, não haveria oscilação jurisprudencial ${ }^{83}$.

Em seguida, o Ministro Cezar Peluso aduziu que uma generalização da modulação dos efeitos em matéria tributária conduziria, invariavelmente, à abolição do instituto da repetição de indébito. $\mathrm{O}$ julgador, no entanto, mais adiante cai no discurso consequencialista ao afirmar 
Ainda se manifestando pela impossibilidade de se dar à decisão efeitos prospectivos, o Ministro Ricardo Lewandowsi enfatizou a rigidez com que o Supremo trata a modulação contra direitos dos Contribuintes. Ademais, lembrou que o instrumento utilizado para tanto mera petição após o início do julgamento da causa não era adequado.

Por fim para encerrar os destaques com relação aos votos contra a modulação de efeitos no caso , convém expor que a Ministra Cármen Lúcia também se alinhou ao quanto dito pelo Ministro Marco Aurélio sobre a necessidade de se assegurar a rigidez constitucional, pois uma mitigação nesse caso poderia conduzir a uma impunidade quanto aos erros do Estado $^{85}$.

A Ministra Ellen Gracie foi a única a votar no sentido da necessidade de modulação. Nas palavras da julgadora:

\footnotetext{
E daria [a modulação de efeitos], Senhor Presidente, porque entendo que o Tribunal ao fazer uma manifestação como a de hoje e não estabelecer limites, está indo na contramão de toda a reforma do Poder Judiciário, está incentivando a criação de milhares de novos processos de primeiro grau.

Encontro, ainda, uma outra dificuldade com relação à matéria de fundo. É que evidentemente esse valor recolhido a título de Finsocial já foi incorporado ao preço pelo qual se venderam as mercadorias, de modo que consistirá, no meu entendimento, enriquecimento indevido a restituição deste tributo. ${ }^{86}$
}

Como se pode notar, os argumentos consequencialistas também estão presentes na intervenção da Ministra.

\section{ii) Comentários}

Percebe-se nesse julgado que o Tribunal se posicionou contra a modulação de efeitos em uma situação que correspondesse aos interesses dos Contribuintes.

No entanto, deve-se ressaltar que o argumento consequencialista ainda influenciou muito a justificação dos votos. Como se pode perceber, a Ministra Ellen Gracie frisou que a ausência de modulação faria com que inúmeros contribuintes pudessem entrar em juízo na contramão de toda a reforma do Poder Judiciário ${ }^{87}$.

Com o devido respeito, tal argumento, todavia, não convence. A função do Poder Judiciário, ainda mais quando se tem em jogo tributos, é evitar que os demais poderes Legislativo e Executivo invadam o patrimônio do particular sem a observância das normas pertinentes. Se tal circunstância infelizmente acontecesse, não se poderia retirar do jurisdicionado o direito de se evadir de tal cobrança ilegal; dever-se-ia exigir, na verdade, um

\footnotetext{
${ }^{85}$ RE n. 363.852

${ }^{86}$ RE n. 363.852

${ }^{87}$ RE n. 363.852
} 
maior rigor na punição daqueles que exigiram indevidamente a exação, criando, assim, o conflito no Judiciário.

A julgadora ainda argumenta que a quantia da exação já foi incorporada ao preço das

Entende-se ser inaceitável que tal discurso consequencialista exposto pela Ministra seja suficiente para se permitir que não se conceda o direito daquele injustamente afetado por uma subtração injusta de seu patrimônio de reavê-lo, sob qualquer fundamento não jurídico isolado.

A preocupação com o argumento consequencialista ainda encontra motivos de

questionamento: quer dizer que se o número de empregados fosse grande a modulação deveria se aplicada? Afigura-se, sob a ótica desenvolvida neste trabalho que, se a cobrança é indevida, não importa o número de afetados, ou mesmo a quantia em debate, devendo-se conceder ao Contribuinte o direito de reaver o dinheiro injustamente transferido aos cofres públicos. 


\section{Considerações finais}

Após essa exposição feita, percebemos que não faltam exemplos, tanto na jurisprudência pátria como na estrangeira, da influência do consequencialismo na modulação de efeitos.

Essa ingerência, em princípio, não pode ser vista como algo nefasto, uma vez que possibilita a resolução de questões difíceis que são postas aos tribunais em especial o STF , de forma a aproximar a declaração de inconstitucionalidade ou uma alteração jurisprudencial dos princípios encampados em nossa constituição.

No entanto, a utilização desse instrumento decisório não pode ser feita de modo desarrazoado, sem que encontre respaldo no Estado Constitucional de Direito, o qual vigora no Brasil.

Dessa forma, o modelo estatal aqui vigente apresenta uma série de mecanismos que acabam por determinar, ao menos em matéria tributária, que os efeitos prospectivos só posam ser aplicados caso a parte prejudicada seja o Contribuinte. Ademais, uma negativa de negativa de tal emprego gera uma forma de enriquecimento ilícito estatal que é por ele mesmo sufragado.

Ainda deve se ressaltar que a modulação em favor da Fazenda federal, estadual ou municipal representa ainda o solapamento de vários princípios e garantias insculpidas no texto constitucional, principalmente os prescritos na Seção II do Capítulo I do Título VI, que

As normas contidas nessa seção representam o mínimo de espaço resguardado ao indivíduo no qual não cabe ao Poder Público invadir ou no qual se permite a intromissão estatal, mas mediante procedimentos claros e específicos.

Essas limitações, no entanto, ao que parece, não estão sendo firmemente observadas pelo órgão de cúpula do Judiciário pátrio o STF. A partir do exame de parte da jurisprudência da Corte, principalmente após a edição do artigo 28 da Lei 9.868/99, percebese que, por vezes, os Ministros não se atrelam aos princípios constitucionais que protegem os direitos fundamentais, especialmente em matéria tributária, e acabam se deixando levar muito mais pela influência que a decisão trará nos cofres públicos.

Além disso, a falta de parâmetros claros para o emprego de efeitos prospectivos faz com que determinadas questões, apesar de serem ventiladas em um caso, sejam totalmente olvidadas na solução de outro, mesmo que com características semelhantes. E é interessante notar que essa peculiaridade acaba influenciando somente a decisão contra os interesses dos Contribuintes. 
Ainda deve-se destacar que essa ratio decidendi adotada pelo STF tem o condão de aumentar a beligerância entre Contribuintes e Fisco. Passa-se a imagem de que, quanto mais as partes recorrerem, maiores são as chances de verem o seu interesse atendido. As circunstâncias de alguns julgados examinados revelaram tal tendência, ainda que somente em favor da Fazenda. De toda a forma, essa é a mensagem que é transmitida implicitamente.

Ademais, a ausência de parâmetros confiáveis capazes de balizar o instituto de modulação de efeito faz com que toda e qualquer questão de direito tributário tenha, como um último argumento a carta na manga os graves danos ao erário.

Essa formula de solução pode apresentar graves riscos. Por isso, com molde do Estado de Direito, propõe-se a sua impossibilidade de utilização quando não for a favor dos indivíduos. Esse arquétipo, além de retirar os jurisdicionados da incerteza jurídica, ainda possibilita a concretização dos valores contidos na nossa Constituição.

Desafios em que o STF deverá enfrentar essa questão não faltam. Espera-se que a orientação da Corte passe a ter os direitos fundamentais como baliza principal. 


\section{Referências Bibliográficas}

ANDRADE, Fábio Martins de. O argumento Pragmático ou Consequencialista de Cunho Econômico e as Decisões do STF. Quartier Latin: São Paulo, 2011.

O conseqüencialismo, a Modulação Temporal dos Efeitos e o Ativismo Judicial nas Decisões do Supremo Tribunal Federal e o Estado de Direito. Revista Dialética de Direito Tributário, n 172, p. 34-43, jan. 2010.

BOBBIO. Norberto. A era dos Direitos. Tradução de Carlos Nelson Coutinho. Rio de Janeiro: Elsevier, 2004.

BRASIL. Constituição (1967). Constituição da República Federativa do Brasil: promulgada em 15 de março de $1967 . \quad$ Disponível em: http://www.planalto.gov.br/ccivil_03/constituicao/Constitui\%C3\%A7ao67.htm, acesso em 09.10.2011.

\begin{tabular}{cccccc}
\multicolumn{4}{c}{. Constituição (1988). Constituição da República Federativa do Brasil: promulgada em } \\
\hline 5 & de & outubro & de & 1988. & Disponível
\end{tabular} http://www.planalto.gov.br/ccivil_03/constituicao/constitui\%C3\%A7ao.htm, acesso em 01.10.2011.

Constituição (1988). Emenda Constitucional no 3, de 17 de Março de 1993. Altera os arts. 40, 42, 102, 103, 155, 156, 160, 167 da Constituição Federal. Disponível em: http://www.planalto.gov.br/ccivil_03/constituicao/emendas/emc/emc03.htm , acesso em 05.10.2011.

Decreto-lei $\mathrm{N}^{\circ} 1.569$, de 8 de agosto de 1977. Modifica o artigo 11do Decreto-lei $\mathrm{n}^{\circ}$ $\overline{352 \text {, de }} 17$ de junho de 1968, alterado pelo artigo $1^{\circ}$ do Decreto-lei $n^{\circ} 623$, de 11 de junho de 1969, e dá outras providências. Disponível em: http://www.planalto.gov.br/ccivil_03/decretolei/Del1569.htm, acesso em 09.10.2011.

Lei $\mathrm{N}^{\mathrm{o}}$ 5.869, de 11 de janeiro de 1973. Institui o Código de Processo Civil. Disponível em: http://www.planalto.gov.br/ccivil_03/leis/L5869.htm, acesso em 05.11.2011.

Lei $N^{\circ}$ 8.212, de 24 de julho de 1992. Dispõe sobre a organização da Seguridade Social, institui o Plano de Custeio, e dá outras providências. Disponível em: http://www.planalto.gov.br/ccivil_03/leis/L8212cons.htm, acesso em 09.10.2011.

Lei $\mathrm{N}^{\circ}$ 8.540, de 22 de dezembro de 1992. Dispõe sobre a contribuição do empregador rural para a seguridade social e determina outras providências, alterando dispositivos da Lei n/s 8.212, de 24 de julho de 1991 e 8.315, de 23 de dezembro de 1991. Disponível em: http://www.planalto.gov.br/ccivil_03/leis/L8540.htm, acesso em 12.10.2011.

Lei $\mathrm{N}^{\circ}$ 9.868, de 10 de novembro de 1999. Dispõe sobre o processo e julgamento da ação direta de inconstitucionalidade e da ação declaratória de constitucionalidade perante o Supremo Tribunal Federal. Disponível em: http://www.planalto.gov.br/ccivil_03/leis/L9868.htm, acesso em 06.10.2011. 
Supremo Tribunal Federal. Ação Declaratória de Constitucionalidade n. 1-DF. Relator: Ministro Moreira Alves. Reqtes.: Presidente da República, Mesa do Senado Federal e Mesa da Câmara dos Deputados. Plenário, 01.12.1993.

Supremo Tribunal Federal. Ação Direta de Inconstitucionalidade n. 513-DF. Relator: Ministro Célio Borja. Reqte.: Partido Democrático Trabalhista. Reqdos.: Presidente da República, Congresso Nacional e Diretor da Receita Federal. Plenário. Julgado em 14.06.1991.

Supremo Tribunal Federal. Ação Direta de Inconstitucionalidade n. 1.102-DF. Relator Ministro Mauricio Corrêa. Reqte.: Confederação Nacional da Indústria. Reqdos: Presidente da República e Congresso Nacional. Plenário, 05.10.1995.

Supremo Tribunal Federal. Ação Direta de Inconstitucionalidade n. 2.154-DF. Relator Ministro Sepúlveda Pertence. Decisão: Após o voto do Senhor Ministro Sepúlveda Pertence (Relator), que declarava, no ponto, a inconstitucionalidade do artigo 27 da Lei $\mathrm{n}^{\circ}$ 9.868/99, pediu vista dos autos a Senhora Ministra Cármen Lúcia. Presidência da Senhora Ministra Ellen Gracie. Plenário, 16.08.2007.

Supremo Tribunal Federal. Ação Direta de Inconstitucionalidade n. 2.240-BA. Relator Ministro Eros Grau. Reqte.: Partido dos Trabalhadores PT. Reqdo.: Governador do Estado da Bahia. Plenário, 09.05.2007.

Supremo Tribunal Federal. Ação Direta de Inconstitucionalidade n. 2.258-DF. Relator Ministro Sepúlveda Pertence. Decisão: Após o voto do Senhor Ministro Sepúlveda Pertence (Relator), que declarava, no ponto, a inconstitucionalidade do artigo 27 da Lei $\mathrm{n}^{\circ}$ 9.868/99, pediu vista dos autos a Senhora Ministra Cármen Lúcia. Presidência da Senhora Ministra Ellen Gracie. Plenário, 16.08.2007.

Supremo Tribunal Federal. Agravo de Instrumento n. 509.534. Relator Ministro Marco Aurélio. Decisão monocrática publicada no Diário de Justiça de 17.11.2004.

Supremo Tribunal Federal. Mandado de Segurança n. 26.604. Relatora Ministra Carmen Lúcia. Plenário, 03.10.2008.

Supremo Tribunal Federal. Recurso Extraordinário n. 46.450-RS. Relator Ministro Vilas Boas. Publicado em 31.05.1961. Resolve o Supremo Tribunal Federal conhecer do recurso, para lhe negar provimento. $2^{\mathrm{a}}$ Turma, em 10.01.1961.

. Supremo Tribunal Federal. Recurso Extraordinário n.79.343-BA. Relator Ministro Leitão de Abreu. Decisão: Conhecido e provido nos termos do voto do relator. Unânime. $2^{\mathrm{a}}$ Turma, em 31.5.1977.

Supremo Tribunal Federal. Recurso Extraordinário n. 78.594-SP. Relator Ministro Bilac Pinto. Decisão: Não conhecido. Unânime. 2a Turma, em 07.6.1974.

Supremo Tribunal Federal. Recurso Extraordinário n. 103.619-RJ. Relator Ministro Oscar Corrêa. Recorrente: Alberto Craveiro de Almeida. Recorrido COMLURB Cia. Municipal de Limpeza Urbana. Decisão: Conheceu-se do Recurso e se lhe deu provimento. Unânime. $1^{\text {a }}$ Turma, 08.02.85. 
Supremo Tribunal Federal. Recurso Extraordinário n. 150.764. Relator Ministro Sepúlveda Pertence. Relator para o acórdão o Ministro Marco Aurélio. Plenário, 16.12.1992.

. Supremo Tribunal Federal. Recurso Extraordinário n. 363.826. Relator Ministro Marco Aurélio. Recte.; Frigorífico Mataboi S/A. Recdo.: União. Plenário, 03.02.2010.

Supremo Tribunal Federal. Recurso Extraordinário n. 370.682. Relator Ministro Ilmar Galvão. Relator para o acórdão Ministro Gilmar Mendes. Recte.: União. Recdo.: Indústrias de Garrafas Plásticas Guará Ltda.. Plenário, 25.06.2007.

. Supremo Tribunal Federal. Recurso Extraordinário n. 556.664-RS. Relator Ministro Gilmar Mendes. Recte.: União. Recdo.: Novoquim Indústria Quimicas Ltda. Plenário, 11.06.2008.

Supremo Tribunal Federal. Recurso Extraordinário n. 559.882-RS. Relator Ministro Gilmar Mendes. Recte.: União. Recdo.: Confecções Três e Um Ltda. e Outro (a/s). Plenário, 11.06.2008.

Supremo Tribunal Federal. Recurso Extraordinário n. 560.626-RS. Relator Ministro Gilmar Mendes. Recte.: União. Recdo.: REDG Consultoria Tributária Sociedade Civil Ltda.. Plenário, 11.06.2008.

. Supremo Tribunal Federal. Súmula n. 546. Publicada no Diário de Justiça no dia 10.12.1969. Inteiro teor disponível em: http://www.stf.jus.br/portal/jurisprudencia/listarJurisprudencia.asp?s1=546.NUME. NAO S.FLSV.\&base=baseSumulas, acesso em 04.10.2011.

Supremo Tribunal Federal. Súmula n.584. Publicada no Diário de Justiça no dia 3.1.1977. Inteiro teor disponível em: http://www.stf.jus.br/portal/jurisprudencia/listarJurisprudencia.asp?s1=584.NUME. NAO S.FLSV.\&base=baseSumulas , acesso em 05.10.2011.

Supremo Tribunal Federal. Súmula Vinculante n. 8. Publicada no Diário de Justiça \begin{tabular}{llll}
\hline Eletrônico de & 12.09.2008. & Disponível em:
\end{tabular} http://www.stf.jus.br/arquivo/cms/jurisprudenciaSumulaVinculante/anexo/DJe_172_2008.pdf ,acesso em 10.10.2011.

Superior Tribunal de Justiça. Súmula n. 276. Publicada no Diário de Justiça no dia 02.06.2003. Disponível em http://www.stj.jus.br/SCON/sumulas/doc.jsp?livre=\%40docn $\&$ processo=276\&\&b=SUMU\&p $=$ true $\& \mathrm{t}=\& \mathrm{l}=10 \& \mathrm{i}=1$, acesso em 10.10.2011.

CANOTILHO, José Joaquim Gomes. Direito Constitucional. 5 $5^{\text {a }}$ Ed. Livraria Almedina: Coimbra, 1992.

CASSONE, Vittório. IPI: decisão em que o Supremo Tribunal Federal negou efeito prospectivo. RE 370.682: leading case. Revista Tributária e de Finanças Públicas, v. 16, n. 80, p. 228-252, mai/jun 2008. 
CASTRO, Leonardo Freitas de Morais e. Segurança jurídica em face da alteração de posicionamento dos Tribunais Superiores: limites da previsibilidade em matéria tributária. Revista tributária e de finanças públicas, v. 18, n. 91, p. 204-249, mar./abr. 2010.

COOLEY, Thomas Mclntyre. A treatise on the constitucional limitations. Little, Brown and company: Boston, 1868.

DERZI, Misabel Abreu Machado. Modificações da jurisprudência: proteção da confiança, boa-fé objetiva e irretroatividade como limitações constitucionais ao poder judicial de tributar. Noeses: São Paulo, 2009.

ESTADOS UNIDOS DA AMÉRICA. Decisão da Suprema Corte. Chevron Oil Co.v. Huson, 404 U.S. 97 (1971). Disponível em: http://supreme.justia.com/us/404/97/case.html , acesso em 02.10.2011.

Department of the Treasury, 489 U.S. 803 (1989). Disponível em: http://supreme.justia.com/us/489/803/case.html, acesso em 02.10.2011.

Decisão da Suprema Corte. Harper ET AL. v. Virginia Department of Taxation, 508 U.S. 86 (1993). Disponível em: http://supreme.justia.com/us/509/86/case.html , acesso em 02.10.2011.

Decisão da Suprema Corte. Linkletter v. Walker, 381 U.S. 618 (1965). Disponível em: http://supreme.justia.com/us/381/618/case.html\#629 , acesso em 01.10.2011.

Decisão da Suprema Corte. Marbury v. Madison, 5 U.S. 137 (1803). Disponível em: http://supreme.justia.com/us/5/137/case.html , acesso em 01.10.2011.

FERREIRA FILHO, Manoel Gonçalves. O papel político do judiciário na ordem constitucional vigente. Revista do Advogado, v. 28, n. 99, p. 86-91. São Paulo: Associação dos Advogados de São Paulo, set. 2008.

GARCIA, Maria. Inconstitucionalidades: o voto de Marshall (1803) e a modulação de efeitos da lei 9.868/1999. Revista de Direito Constitucional e Internacional, v. 18, n. 73, p. 206223, out./dez. 2010.

JOBIM, Nelson. Judiciário favorece aumento de juros, diz Nelson Jobim: Entrevista com o Ministro Nelson Jobim. Jornal Valor Econômico, São Paulo, 13.12.2004. Entrevista concedida a Juliano Basile e Thiago Vitale Jayme.

KELSEN, Hans. Teoria Pura do Direito. Tradução: João Baptista Machado. $7^{\text {a }}$ Ed. Martins Fontes: São Paulo, 2006.

LEAL, Rogério Gesta. Impactos econômicos e sociais das decisões judiciais: aspectos introdutórios. Enfam: Brasília, 2010. Disponível em: http://bdjur.stj.gov.br/xmlui/handle/2011/32233, acesso em 01.11.2011. 
MELO, José Eduardo Soares de. Curso de direito tributário. $8^{\text {a }}$ Ed. Dialética: São Paulo, 2008.

MENDES, Gilmar Ferreira; COELHO, Inocêncio Mártires; BRANCO, Paulo Gustavo Gonet. Curso de Direito Constitucional. $4^{\text {a }}$ Ed. Saraiva: São Paulo, 2009.

MONTESQUIEU, Charles-Louis de Secondat de. De l'esprit des lois. Librairie Garnier Frères: Paris, 1927.

REICHELT, Luis Alberto. A duração do proesso: o julgamento do recurso extraordinário dotado de repercussão geral e a modulação dos efeitos da declaração de inconstitucionalidade. Revista de processo, v. 36, n. 193, p. 131-250, mar. 2011.

ROUSSEAU, Jean-Jacques. O contrato social: princípios de direito político. Tradução de Antonio de Pádua Danesi. $4^{\mathrm{a}}$ Ed. Martins Fontes: São Paulo, 2006.

SABBAG, Eduardo. Manual de Direito Tributário. Saraiva: São Paulo, 2009.

SILVA. José Afonso da. Curso de direito constitucional positivo. $5^{\text {a }}$ Ed. Revista dos Tribunais: São Paulo, 1989.

SUNDFELD. Carlos Ari. Fundamentos de Direito Público. $4^{\mathrm{a}}$ Ed. Malheiros: São Paulo, 2006.

TAVARES, Alexandre Macedo. A Responsabilidade Estatal pelo Desempenho irregular da Função de legislar como Engrenagem do Sistema de Freios e Contrapesos à Possibilidade de o STF atribuir Eficácia Prospectivas às Decisões de Inconstitucionalidade em Matéria Tributária. Revista Dialética de Direito Tributário. São Paulo: Dialética, $\mathrm{n}^{\circ}$ 159, p. 7-18, dez. 2008.

e do ativismo de caráter jurisdicional. Direitos Fundamentais e Justiça, v. 3, n.7, p. 167181, abr./ jun. 2009.

TORRES, Ricardo Lobo. O consequencialismo e a Modulação dos Efeitos das Decisões do Supremo Tribunal Federal. In: DERZI, Misabel Abreu Machado (Coord.). Separação de Poderes e Efetividade do Sistema Tributário. Belo Horizonte: 2010.

dos efeitos da pronúncia de inconstitucionalidade em matéria tributária. Revista Dialética de Direito Tributário. São Paulo: Dialética, $\mathrm{n}^{\circ}$ 157, p.7-16, out., 2008.

ZOLO, Danilo Teoria e crítica do Estado de Direito. In: O Estado de Direito: história, teoria, critica. COSTA, Pietro; ZOLO, Danilo (orgs.). Tradução: Carlos Alberto Dastoli. Martins Fontes: São Paulo, 2006. 